\title{
AVALIAÇÃO DE CARACTERÍSTICAS MORFOFISIOLÓGICAS E NUTRICIONAIS DO CAPIM TOBIATÃ (Panicum maximum CV. TOBIATÃ) SOB SISTEMA DE PASTEJO ROTACIONADO
}

\author{
EDMAR IMPERATRICE TEIXEIRA \\ Zootecnista
}

Orientador: Prof. Dr. WILSON R. SOARES MATTOS

Dissertação apresentada à Escola Superior

de Agricultura "Luíz de Queiroz",

Universidade de São Paulo, para obtenção

do título de Mestre em Agronomia, Área de

Concentração: Ciência Animal e Pastagem.

P I R A C I C A B A

Estado de São Paulo - Brasil

Janeiro - 1998 
Dados Internacionais de Catalogação na Publicação (CIP) DIVISÃo DE BIBLIOTECA E DOCUMENTAÇÃO - Campus "Luiz de Queiroz"/USP

\author{
Teixeira, Edmar Imperatrice \\ Avaliação de caracteristicas morfofisiológicas e nutricionais do capim Tobiatā \\ (Panicum maximum cv. Tobiatā) sob sistema de pastejo rocacionado / Edmar \\ Imperatrice Teixeira. - Piracicaba, 1998. \\ $87 \mathrm{p}$.
}

Dissertaçāo (mestrado) - Escola Superior de Agricultura Luiz de Queiroz, 1998. Bibliografia.

1. Digestibilidade 2. Fisiologia vegetal 3. Graminea forrageira tropical 4. Matéria seca 5. Morfologia vegetal 6. Propriedade fisico-química do solo 7. Valor nutritivo I. Titulo 


\section{CARACTERÍSTICAS MORFOFISIOLÓGICAS E NUTRICIONAIS DO CAPIM TOBIATÃ (Panicum maximum CV. TOBIATÃ) SOB SISTEMA DE PASTEJO ROTACIONADO}

\section{EDMAR IMPERATRICE TEIXEIRA}

Aprovada em: 30.07 .1998

Comissão julgadora:

Prof. Dr. Wilson Roberto Soares Mattos

Prof. Dr. Flávio Portella Santos

Prof. Dr. Luís Roberto de Andrade Rodrigues
ESALQ/USP

ESALQ/USP

FMVAJ/UNESP

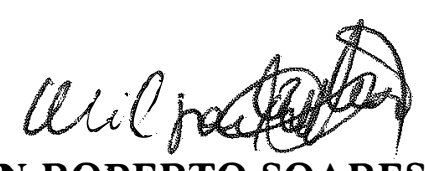

Prof. Dr. WILSON ROBERTO SOARES MATTOS

Orientador 


\section{AGRADECIMENTOS}

- Ao mestre Prof. Wilson R. S. Mattos pelo apoio, encorajamento e companheirismo.

- Ao Prof. Luís Gustavo Nussio pelos ensinamentos e pelas oportunidades dadas

- Aos professores Vidal Pedroso de Faria e Moacyr Corsi pelo exemplo de caráter e profissionalismo.

- Ao Prof. Sila Carneiro da Silva pelos esclarecimentos e orientações.

- Ao Prof. Flávio Portella Santos e ao Prof. Luíz Roberto de Andrade Rodrigues pelas sugestões e correções deste trabalho.

- Ao Dr. Arthur C. de Camargo pelo exemplo de perseverança e trabalho.

-Ao Eng ${ }^{\circ}$ Agron ${ }^{0}$ Frederico A. de Andrade Rosseto pelo auxilio técnico.

- Ao Zootecnista Edson Gonçalves pela compreensão e amizade.

- Ao técnico de laboratório Carlos César Alves pelo treinamento.

- À Eng ${ }^{\mathrm{a}}$ Agron $^{\mathrm{a}}$ Roberta Carnevalli pelo auxilio técnico e amizade.

- À Eng ${ }^{\mathrm{a}}$ Agron ${ }^{\mathrm{a}}$ Carmen S. Pires Teixeira por tudo. 


\section{DEDICATÓRIA}

Aos meus amigos e acompanhantes dessa jornada:

Edmar e Cleusa,

Pedro e Isabel.

Moisés e Roque e

a minha companheira Carmen.

Dedico esse trabalho, como tentativa de retribuir uma pequena parte do muito que me ofereceram. 


\section{SUMÁRIO}

Página

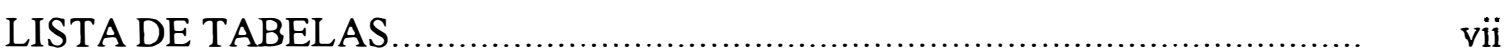

LISTA DE ABREVIATURAS E SÍMBOLOS …….................................... ix

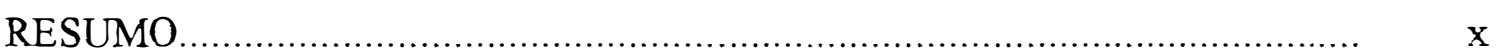

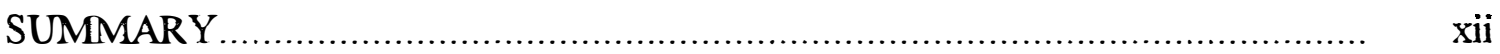

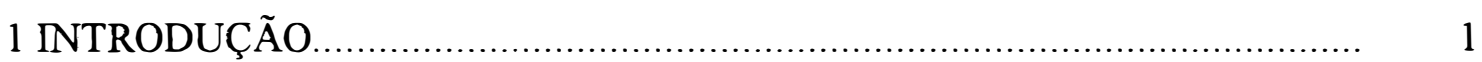

2 REVISÃO DE LITERATURA …............................................................. 3

2.1 Potencial de produção de leite e taxa de lotação ............................................. 3

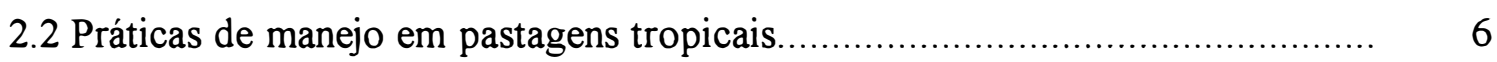

2.3 Produção de matéria seca das gramineas tropicais ......................................... 10

2.4 Eficiência de colheita das pastagens........................................................ 14

2.5 Valor nutritivo da forragem sob pastejo..................................................... 16

2.6 Fluxo de tecidos e morfogênese em pastagens............................................ 22

3 MATERIAL e MÉTODOS ...................................................................... 31

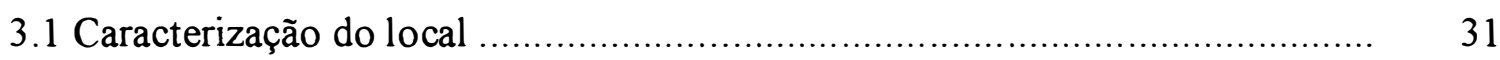

3.2 Características químicas do solo e adubação................................................ 31

3.3 Manejo da pastagem e dos animais........................................................... 32

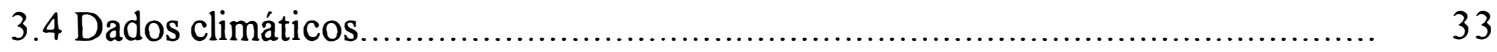

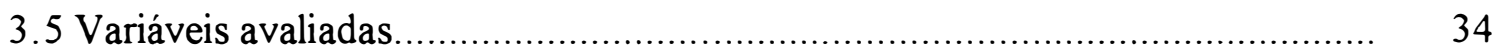

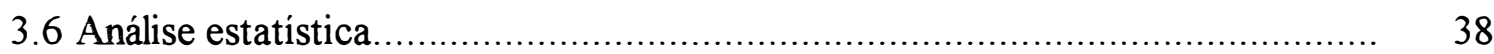

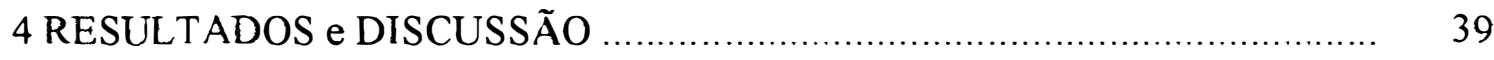

4.1 Produção, utilização e fracionamento da forragem......................................... 39

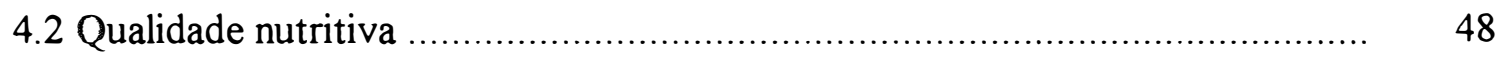

4.3 Filocrono e taxa de aparecimento de folhas............................................ 57 


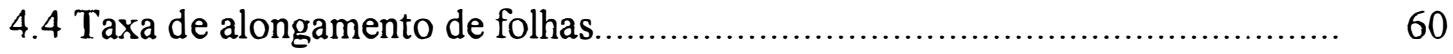

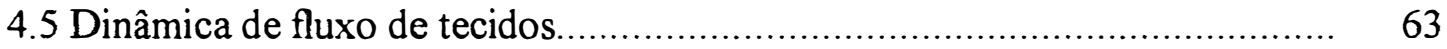

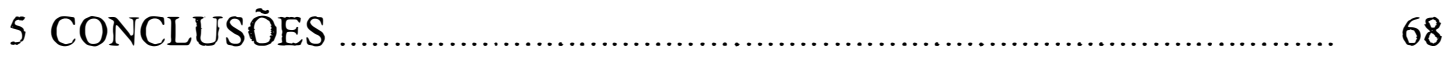

6 REFERÊNCIAS BIBLIOGRÁFICAS _................................................. 70 


\section{LISTA DE TABELAS}

Página

1 Características químicas do solo $(0 \mathrm{a} 20 \mathrm{~cm})$

da área experimental.

2 Dados climáticos e estimativa de acúmulo

de GD do local do experimento, durante o período

de outubro de 1995 a maio de 1996

3 Variáveis relacionadas com a disponibilidade

de MS da planta toda, resíduo pós-pastejo e

perdas de pastejo

4 Estimativa da dinâmica de utilização e

acúmulo de MS da pastagem

5 Variáveis relacionadas à componentes de

pastejo e desempenho animal

6 Variáveis relacionadas com produção e

fracionamento da planta toda

7 Variáveis relacionadas com produção e

fracionamento do resíduo pós-pastejo

8 Variáveis relacionadas com a produção e

fracionamento da planta toda e do

resíduo pós-pastejo

9 Análise bromatológica e DIVVMS de folhas

na planta toda.

10 Análise bromatológica de folhas no resíduo pós-pastejo.

11 Análise bromatológica de hastes na planta toda 
12 Análise bromatológica de hastes no resíduo pós-pastejo .......

13 Análise bromatológica das diferentes frações da planta (pastejo simulado, folhas e hastes da planta toda, folhas e hastes do resíduo pós-pastejo)

14 Análise bromatológica e DIVVMS de pastejo simulado ..... 56

15 Medidas de filocrono e taxa de aparecimento de folhas ...... 58

16 Taxa de alongamento de folhas e de folhas/perfilho ............ 61

17 Número de folhas vivas expandidas/perfilho........................ 64

18 Número de folhas em expansão/perfilho ............................ 65 


\section{LISTA DE ABREVIATURAS E SÍMBOLOS}

$\begin{array}{ll}\text { AOAC } & \text { Association of Official Analytical Chemists } \\ \text { DIVMS } & \text { digestibilidade in vitro da matéria seca } \\ \text { DIVVMS } & \text { digestibilidade in vitro verdadeira da matéria seca } \\ \text { EL } & \text { energia líquida } \\ \text { FDA } & \text { fibra insolúvel em detergente ácido } \\ \text { FDN } & \text { fibra insolúvel em detergente neutro } \\ \text { GD } & \text { graus-dia } \\ \text { IAF } & \text { indice de área foliar } \\ \text { LIG } & \text { lignina } \\ \text { MM } & \text { matéria mineral } \\ \text { MO } & \text { matéria orgânica } \\ \text { MS } & \text { matéria seca } \\ \text { NDT } & \text { nutrientes digestíveis totais } \\ \text { PB } & \text { proteina bruta } \\ \text { PV } & \text { peso vivo } \\ \text { UA } & \text { unidade animal }\end{array}$




\title{
CARACTERÍSTICAS MORFOFISIOLÓGICAS E NUTRICIONAIS DO CAPIM TOBIATÃ (Panicum maximum CV. TOBIATÃ) SOB SISTEMA DE PASTEJO ROTACIONADO
}

\author{
Autor: EDMAR IMPERATRICE TEIXEIRA \\ Orientador: Prof. WILSON ROBERTO SOARES MATTOS
}

\section{RESUMO}

Esse trabalho objetivou descrever a dinâmica do fluxo de tecidos, a qualidade nutricional, eficiência de pastejo e a composição de uma pastagem de capim Tobiatã (Panicum maximum cv. Tobiatã) pastejada num ciclo de 34 dias (33 dias de descanso e 1 dia de ocupação) durante os meses de novembro de 1995 a maio de 1996.

Foi utilizada uma área de pastagem de 3,3 ha de capim Tobiatã estabelecido no Centro de Pesquisa de Pecuária do Sudeste (CPPSE-EMBRAPA) de São Carlos-SP. Após cada pastejo foram coletados dados relacionados à produção e às perdas pós-pastejo. A qualidade nutricional das hastes e folhas, tanto do material disponivel quanto do resíduo pós-pastejo, foram obtidas através de análises bromatológicas. Variáveis relacionadas com a morfofisiologia da planta como: taxa de alongamento de folhas, taxa de aparecimento de folhas, filocrono em dias e graus dia e números de folhas verdes e senescentes foram analisadas e comparadas entre os ciclos de pastejo ou meses de observação. A disponibilidade média de forragem antes da entrada dos animais na pastagem foi de $12.374 \mathrm{~kg}$ de MS/ha, o que permitiu uma lotação média de $11,88 \mathrm{UA} / \mathrm{ha}$ durante o período experimental. Os dados obtidos demonstraram uma queda na eficiência de pastejo de 65,0 para 20,6 \% à medida em que os ciclos de pastejo avançaram. Esse fato foi atribuido ao aumento da quantidade total de resíduo pós-pastejo, à redução da 
qualidade nutricional e alteração das frações da forragem disponivel. A taxa média de alongamento de folhas foi de $4,05 \mathrm{~cm} /$ folha.dia, o filocrono de 10,22 dias/folha ou 147,93 graus-dia. O número máximo de folhas vivas expandidas observado foi de 4,85 folhas durante o final da estação de pastejo e o número máximo de folhas em expansão foi em média de 1,92 folhas no periodo. A produção média de leite por vaca em lactação foi de $30,63 \mathrm{~kg}$ de leite/animal.dia, sendo que a disponibilidade de forragem/peso animal foi em média de 7,0 \% PV. Foi observada uma queda na digestibilidade in vitro verdadeira da matéria seca (DIVVMS) da forragem coletada através do pastejo simulado do início para o final do periodo experimental. Em média a DIVVMS do pastejo simulado apresentou valor de $80,1 \%$.

PALAVRAS CHAVE: Panicum maximum, Tobiatã, pastejo rotacionado, eficiência de pastejo, resíduo pós-pastejo, produção de matéria seca, fluxo de tecido, filocrono, digestibilidade. 


\title{
MORFOPHYSIOLOGICAL AND NUTRITIONAL FEATURES OF TOBIATÃ GRASS (Panicum maximum CV. TOBIATÃ) UNDER ROTATIONAL GRAZING
}

\author{
Author: EDMAR IMPERATRICE TEIXEIRA \\ Adviser: Prof. WILSON ROBERTO SOARES MATTOS
}

\section{SUMMARY}

The objectives of this research were to describe tissue turnover, forage quality and composition of a Tobiatã grass pasture (Panicum maximum cv. Tobiatã). The grazing cicle was 34 days ( 33 days of resting period and 1 day of grazing period) from November 1995 to May 1996. The experimental plots were estabilished in 3.3 ha at CPPSE-EMBRAPA, São Carlos-SP. Total dry matter production, quality and losses were measured before and after grazing. The forage quality of stems and leaves of the residue and total available forage were chemically analysed. Data related to tissue turnover, i.e. leaf elongation rates, leaf appearance rates, phyllochron (measured in days and degree-days), number of green and dead leaves were evaluated between the grazing cycles or months. The average total forage availability during the grazing cycles were $12,344 \mathrm{~kg} / \mathrm{ha}$. A stocking rate of 11.88 animal units/ha was observed during the experimental period. There was a decrease in the grazing efficiency from 65.0 to $20.6 \%$ from the begining to the end of the experimental period. This was attributed to the increase in the post grazing residue, forage quality reduction, and plant fractions changes. The average elongation rate was $4.05 \mathrm{~cm} /$ leaf.day, the phyllochron was 10.22 days/leaf and 142.93 degrees-day/leaf. The maximum number of green leaves observed was 4.85 leaves/tiller. The maximum number of expanding leaves was 1.92 per tiller. The average 
animal production was $30.63 \mathrm{~kg} / \mathrm{cow}$. day and the availability of the period equal to $7.0 \%$ LW. The in vitro "true" dry matter digestibility of simulated grazing decreased from the begining to the end of the grazing season. The mean value observed was $80.1 \%$.

KEY WORDS: Panicum maximum, Tobiatã, rotational grazing, grazing efficiency, post grazing residue, dry matter production, tissue turnover, phyllochron, digestibility. 


\section{INTRODUÇÃO}

A produção de matéria seca numa pastagem é função de fatores inerentes ao ambiente como temperatura e radiação, e de fatores passíveis de serem alterados pelo homem, tais como disponibilidade de nutrientes e de água. Além disso, as técnicas de manejo empregadas numa pastagem podem influenciar na sua dinâmica de produção e utilização.

Sendo um dos objetivos da atividade pecuária a maximização da receita líquida por unidade de área utilizada e, sabendo-se que, as relações de custo pouco são alteradas para um nível de utilização de insumos, o esforço do produtor deve ser direcionado no aumento de eficiência de produção e de colheita da forragem disponível (Nabinger, 1997).

Inúmeros trabalhos científicos têm sido feitos para identificar variáveis que permitam ao produtor definir o momento e a forma ideal de empregar práticas de manejo nas pastagens. Decisões quanto ao nível e momento de reposição de nutrientes, freqüência e intensidade de colheita da forragem, são alguns dos principais pontos de tomada de decisão no campo. 
As forrageiras tropicais caracterizam-se pela capacidade de produzir grandes quantidades de matéria seca por hectare, tendo portanto um potencial de suportar taxas de lotação também elevadas. Para que a conversão de forragem em produto animal por unidade de área seja maximizada são necessários dois fatores: 1) a ingestão de nutrientes deve ser compatível com a produção animal desejada para o sistema de produção em questão. Para tal, são necessários animais com potencial genético para converter a biomassa vegetal em produtos animais (carne, leite ou lã) da forma mais eficiente possivel; 2) a colheita do material disponível deve ser maximizada. O material deixado após o pastejo deve ser o mínimo necessário para permitir uma rebrota vigorosa e a perenidade dessa pastagem, porém, sem comprometer o desempenho animal devido a limitações de consumo ou da qualidade nutricional da forragem consumida.

As espécies do gênero Panicum são de grande utilização no território nacional e apresentam-se como um dos materiais de maior potencial de produção e diversificação de genótipos (Jank, 1994). No entanto, aspectos relacionados com a fisiologia dessas forrageiras devem ser melhor definidos para confirmar ou ajustar procedimentos de manejo propostos na literatura (Barbosa et al. ,1997).

Com o intuito de gerar subsídios para produção e utilização racional do cultivar Tobiatã ( $P$. maximum cv. Tobiatã) este trabalho teve por objetivo descrever alguns aspectos morfofisiológicos dessa gramínea, durante o período das "águas", sob pastejo rotacionado com vacas em lactação. 


\section{REVISÃO DE LITERATURA}

\subsection{Potencial de produção de leite e taxa de lotação}

Sendo a produtividade animal ( $\mathrm{kg}$ de produto animal $/ \mathrm{ha}$ ) de um dado sistema de produção, função da lotação (animais/ha) e do desempenho animal (kg de produto/animal), as práticas de manejo de pastagem devem ser voltadas para a manipulação dessas variáveis. Nesse contexto, o desempenho animal apresenta uma amplitude reduzida de resposta, possuindo um menor potencial de alteração da produtividade quando comparado com a taxa de lotação (Silva \& Pedreira, 1997).

Humphreys (1991) afirmou que a determinação da taxa de lotação numa dada disponibilidade de forragem, define o desempenho animal, a sustentabilidade da produção do pasto e por conseguinte, a viabilidade econômica da atividade pecuária. Esse autor demonstrou que à medida que a lotação da pastagem aumenta, a produção animal por área responde quadraticamente enquanto que a produção por animal sofre um decréscimo linear

Valle et al. (1987) citaram produções a pasto da ordem de $8,5 \mathrm{~kg}$ de leite/animal.dia em capim elefante, sem fazer uso de qualquer suplementação. Produções de leite de 11,7 litros/animal.dia, também obtidas em pastagens de capim elefante durante 
o período das águas, foram medidas por Assis (1997), permitindo uma produtividade de 11.725 litros/ha num período de 180 dias de pastejo. Esse valor ainda está aquém dos 15.000 litros/ha sugeridos por Corsi (1986) como meta plenamente atingivel em pastagens tropicais.

Uma das formas de tais índices serem atingidos é através da obtenção de elevadas taxas de lotação nas gramíneas tropicais. Silva et al. (1995) relataram taxas de lotação médias anuais de 11,1 UA/ha em pastagens de capim elefante, com valores de até 21 UA/ha no período das “águas" em pastos intensificados a mais de 20 anos.

O desempenho animal é função do consumo de matéria seca e da eficiência de conversão desse material em produto animal. Segundo Hodgson (1990), o consumo de forragem em pastejo é influenciado por três fatores. Primeiro, os fatores que afetam a digestão da forragem, relacionados principalmente com a concentração de nutrientes da forragem e sua disponibilidade para o herbivoro. Em segundo, aqueles relacionados com o animal, como capacidade digestiva e de consumo, função de seu estado produtivo e categoria. E finalmente aqueles que afetam a ingestão, relacionados com a morfologia da planta e portanto sobre a facilidade de apreensão da forragem. Caird \& Holmes (1985) citam que a digestibilidade da forragem só afeta o consumo quando a sua disponibilidade não é fator limitante.

O consumo da forragem disponível, portanto, é variável em função de aspectos morfológicos da planta, que adapta-se de forma plástica às diferentes condições de manejo a que é submetida, alterando características de sua estrutura, como por exemplo, a densidade da forragem ( $\mathrm{kg} \mathrm{MS/ha.cm).} \mathrm{Quanto} \mathrm{maior} \mathrm{a} \mathrm{densidade} \mathrm{da} \mathrm{forragem,} \mathrm{seja}$ 
pela maior densidade de perfilhos ou pelo tipo de arquitetura foliar, mais fácil é a apreensão das folhas pelo herbívoro (Stobbs, 1973a). Hodgson (1990) afirma que variáveis do comportamento de pastejo, como quantidade de matéria seca por bocado, são sensíveis à variações na densidade e disponibilidade de forragem. Stobbs (1973b) observou um aumento da densidade do bocado de $0,13 \mathrm{~g}$ para 0,39g de matéria orgânica, quando a densidade de Setaria sphacelata cv. Kazungula passou de $72 \mathrm{~kg}$ para $215 \mathrm{~kg}$ de MO/ha.cm. Hernandez et al. (1990) encontraram valores de densidade da ordem de 84 a $98 \mathrm{~kg}$ de MS/ha.cm para capins do gênero Panicum e citam que valores acima de $200 \mathrm{~kg}$ MS/ha.cm são comuns em gramíneas temperadas, este fato pode ser uma das prováveis causas do menor consumo das forrageiras cespitosas tropicais pelos animais em pastejo.

Apesar dos valores médios de produção de leite à pasto relatados na literatura estarem em torno de 10 a 15 kg/animal.dia, Camargo (1994) observou produções acima de $21 \mathrm{~kg} /$ vaca.dia com animais pastejando capim elefante e Tobiatã. Esses animais foram suplementados com concentrado na proporção de $1,0 \mathrm{~kg}$ para cada $2,7 \mathrm{~kg}$ de leite produzidos. Com o uso de alimentos concentrados, elevadas lotações de pastagem podem ser associadas com desempenhos individuais também elevados, permitindo o alcance de indices de produtividade extremamente altos (Faria et al. ,1993).

No entanto, a produtividade animal depende não só do potencial de produção das forrageiras, mas também da eficiência de colheita desse material pelo animal. Num dado nivel de produção de biomassa vegetal pode-se obter diversas combinações entre lotação e produção animal que, consequentemente, podem definir a viabilidade econômica do sistema (Corsi et al., 1994). 


\subsection{Práticas de manejo em pastagens tropicais}

Alguns autores (Brougham, 1957; Corsi, 1988; Santos, 1993; Gomide, 1988) vem procurando estipular valores que possam guiar o produtor na definição da intensidade, frequêencia e disponibilidade de MS ideal para as diferentes espécies forrageiras tropicais. Brougham (1957) sugeriu o corte das forragens quando estas estivessem próximas de sua máxima eficiência fotossintética, ponto onde as taxas de crescimento seriam também máximas. Esse ponto foi definido pelo índice de área foliar (IAF). Quanto maior o IAF, maior a quantidade de tecido potencialmente fotossintetizante por unidade de área para uma determinada espécie vegetal. Gomide (1994) lembra que tal conceito é relativo ao tipo de crescimento sigmoidal apresentado pelas forrageiras após o corte ou pastejo. Num primeiro momento após o corte, onde o IAF é mínimo, as taxas de crescimento são mínimas e crescentes. Segue-se uma segunda fase de crescimento linear onde as taxas de crescimento são máximas e constantes (aumento linear do IAF). Assim o momento do corte seria próximo ao IAF ótimo, ponto a partir do qual dar-se-ia início o processo de senescência das folhas inferiores da planta (Gomide, 1997). Costa (1990) estudando os cultivares de Panicum maximum, Tobiatã e Colonião, encontrou um IAF médio de 3,95 e 4,39, respectivamente.

Blaser et al. (1986) citam outras maneiras de definir a época de corte das forragens, dentre elas o teor de carboidratos de reserva. Tais produtos da fotossíntese são acumulados em determinadas partes da planta, na base dos colmos no caso das 
gramíneas, quando a produção de carboidratos excede a demanda pelos drenos metabólicos (Harris, 1978, citado por Corsi \& Nascimento, 1994). Nesse caso preconiza-se a desfolha da planta quando esta atingir o acúmulo máximo de reservas energéticas, a ponto de permitir uma rebrota vigorosa da mesma. Herling et al. (1995) estudaram os teores de carboidratos de reserva nos cultivares de Panicum maximum, Colonião e Centenário. Esses autores obtiveram os valores de 4,7; 2,9; e 4,3\% de carboidratos não estruturais totais em capim Centenário aos 0,5 e 25 dias de rebrota. Da mesma forma no capim Colonião o teor de carboidratos recuperou-se de 14 a 21 dias após o corte, após apresentar uma queda de 8 para $4 \%$ na base da planta aos 5 dias (Gomide \& Zago, 1982). Botrel \& Gomide (1981) relatam também para capim Jaraguá (Hiparrenia rufa) uma queda dos carboidratos de reserva aos 7 dias pós-pastejo com recuperação aos 28 dias.

Fulkerson \& Slack (1994) trabalhando com azevém perene (Lolium multiflorum) encontraram correlação do teor de carboidrato com a rebrota apenas até a emissão das primeira folhas. A partir desse ponto o acúmulo de carboidratos parece ter sido governado pela fotossíntese das folhas recentemente expandidas. Da mesma forma Gomide et al. (1979) observaram que a matéria seca foliar do capim Colonião após 21 dias de rebrota esteve mais correlacionada com a preservação dos meristemas apicais ( $\mathrm{r}=$ $0,95)$ do que com o teor de carboidratos na base do caule da planta $(r=0,74)$; esta última foi significativa apenas durante a primeira semana de rebrota.

Outro parâmetro utilizado no manejo de pastagens é a preservação dos meristemas apicais (Corsi \& Nascimento, 1994). Nascimento et al. (1980) observaram 
correlação positiva da rebrota de gramíneas tropicais com a porcentagem de meristemas apicais remanescentes após o pastejo. A preservação dos pontos de crescimento permite uma rápida reposição de folhas, de forma que taxas de crescimento elevadas são atingidas num menor período após o corte. Andrade \& Gomide (1971) observaram em capim elefante cv. Taiwan A-146 que aos 28 dias de rebrota, $16 \%$ dos meristemas apicais foram eliminados com corte rente ao solo. Nessa situação, o vigor da rebrota foi de $1.610 \mathrm{~kg} / \mathrm{ha}$ em 28 dias. Quando o corte foi efetuado aos 56 dias, $100 \%$ dos meristemas foram eliminados e o vigor da rebrota foi reduzido para $451 \mathrm{~kg} / \mathrm{ha}$ em 28 dias. Corsi \& Nascimento (1994) advertem porém que esse tipo de manejo pode implicar na utilização limitada do potencial de crescimento das forrageiras de clima tropical. Havendo disponibilidade de fatores de crescimento (luz, temperatura, água, nutrientes), a rápida elevação do meristema apical é inevitável, sendo freqüente sua eliminação pelo pastejo.

Todas essas ferramentas de manejo visam obter rebrotas vigorosas para maximizar as taxas de crescimento da forragem e manter a perenidade e estabilidade da comunidade de plantas forrageiras (Blaser et al. ,1986).

Um conceito mais abrangente no manejo de pastagens é o de que o mesmo tenha como objetivo primário a maximização da ingestão de nutrientes por unidade área (Humphreys, 1991). Essa meta só é atingida se o enfoque do manejo for a otimização do balanço entre crescimento, perdas e colheita da forragem (Parsons et al., 1988).

Humphreys (1991) afirma que a obtenção de taxas máximas de crescimento e o ponto ótimo de produção líquida de forragem são metas antagônicas, devido às altas 
perdas por senescência e decomposição de folhas com o avançar da maturidade da forragem.

Sabendo então da necessidade da definição de uma determinada frequêencia e intensidade de pastejo, condizentes com o padrão de crescimento de cada espécie de gramínea tropical, vários autores (Brougham, 1957; Corsi, 1988; Santos 1993; Gomide, 1988) sugeriram técnicas que permitissem ao produtor estabelecer o período de descanso, o nível de adubação e a altura de pastejo ideais para a obtenção da perenidade e de altas produtividades dessas forrageiras.

No entanto, tais técnicas não se basearam na dinâmica de desenvolvimento da planta, ou seja, no estudo do fluxo de tecidos da forrageira. Foram baseadas, na verdade, em aspectos relativos à obtenção de vigor de rebrota e elevado valor nutritivo da forragem.

Não apenas a maximização da produtividade deve ser atingida com o manejo racional dos pastos, mas também a otimização do balanço entre crescimento e perdas, colhendo-se o material no ponto de maior acúmulo líquido de matéria seca, promovendo sua máxima utilização (Hodgson ,1990).

Corsi et al. (1994) afirmam que através da mensuração da longevidade das folhas e do número médio de folhas vivas por perfilho é possível determinar o ponto ótimo de colheita da forragem. Deve-se definir o ponto a partir do qual para cada folha que aparece, ocorra a morte da folha mais velha do perfilho. Maximiza-se assim, a eficiência de colheita por reduzir-se ao máximo as perdas por senescência e decomposição da forragem. Esse conceito não é necessariamente contraditório em 
relação ao IAF e aos teores carboidratos de reserva, pois o ponto de tomada de decisão ainda situa-se próximo do ponto de inflexão da curva sigmóide de crescimento das forragens. Esses autores definem então que as práticas de manejo de pasto devem buscar o ponto ótimo de colheita da planta forrageira (mínima perda), que pode ser definido pela mensuração da taxa de aparecimento e senescência de folhas, ou seja, pelo estudo do fluxo de tecidos na comunidade forrageira, associada à ontogenia de perfilhos.

O pastejo do capim Tobiatã em sistemas intensivos vem sendo feito nos mesmos moldes das demais espécies de Panicum. Santos (1993) sugere que o manejo dessa espécie seja em sistema rotacionado, com aproximadamente 30 a 35 dias de intervalo entre pastejos e de 1 a 5 dias de período de ocupação durante o período das águas.

\subsection{Produção de matéria seca das gramíneas tropicais}

De forma geral, as gramíneas tropicais caracterizam-se por possuir elevada produção de matéria seca. Tal fato é explicado por uma maior eficiência fotossintética, quando comparadas com as espécies de clima temperado (Hay \& Walker, 1989). A via fotossintética das gramíneas tropicais difere em eficiência de captação do $\mathrm{CO}_{2}$ atmosférico, sendo maior que nas temperadas. Suas folhas apresentam um anel de células que circunda a bainha foliar (anatomia Kranz) onde a enzima fosfoenol piruvato carboxilase (PEP-carboxilase) fixa o $\mathrm{CO}_{2}$ em um composto de quatro carbonos, o ácido oxaloacético (AOA) . Essa etapa suplementar para as plantas definidas como de ciclo $\mathrm{C}_{4}$ 
implica numa maior taxa fotossintética, menor fotorespiração, e menor consumo de água por unidade de matéria seca produzida, quando comparada com as temperadas ( $\left.\mathrm{C}_{3}\right)$. Essas últimas fixam o $\mathrm{CO}_{2}$ apenas pelo ciclo de Calvin, que também está presente nas $\mathrm{C}_{4}$ e ocorre após a conversão do AOA em malato ou aspartato (Awad \& Castro, 1983).

A produção de forragem por área é função basicamente da integração de duas variáveis: o IAF e a taxa de assimilação aparente, essa última eqüivalendo à taxa de fotossintese líquida. Enquanto o IAF dá uma noção de quantidade de tecido fotoassimilador, a taxa de assimilação aparente reflete a eficiência desse sistema em produzir matéria seca por unidade de tempo/área foliar (Magalhães, 1979).

Vários fatores limitam a taxa de fotossíntese das plantas, permitindo a expressão de apenas parte do seu potencial de crescimento: estresse hídrico (Hsiao, 1973), sombreamento (Bjorkman, 1989), deficiências nutricionais, principalmente de nitrogênio (Hall, 1972). Bolton \& Brown (1980) em trabalhos com Panicum maximum observaram que o aumento de uma unidade percentual no teor de nitrogênio na folha promovia uma elevação de $9,7 \mathrm{mg} \mathrm{CO} 2 / \mathrm{dm}^{2}$.h na taxa de fotossintese aparente. Assim, as produções observadas no campo refletem apenas uma pequena parte do potencial genético das forrageiras. Através de práticas de manejo e do conhecimento da fisiologia dessas plantas, pode-se reduzir esses fatores de estresse e permitir uma maior expressão do seu potencial (Hay \& Walker, 1989).

Produções de matéria seca da ordem de 80 t/ha.ano do capim elefante são descritas por Silva et al. (1995). Corsi \& Santos (1995) relatam um potencial de produção para espécies do gênero Panicum ao redor de $53 \mathrm{t} \mathrm{MS} / \mathrm{ha}$.ano, que raramente é 
conseguido, provavelmente devido ao desconhecimento de suas exigências e características morfofisiológicas.

A produção das forrageiras tropicais varia grandemente com o genótipo (Aguiar, 1997). Rodrigues \& Rodrigues (1987) citam produções de diferentes gramíneas tropicais variando de $14,3,25,3$ e 32,9 t de MS/ha.ano para M. minutiflora, P. maximum e $P$. purpureum, respectivamente.

Mesmo dentro de um determinado gênero grandes diferenças são observadas. Estudando diferentes cultivares de Panicum, Machado et al. (1997) observaram produções de matéria seca verde total de $11,0,16,6,17,2,19,0$ e 21,2 t de MS/ha.ano para os cultivares Colonião, Tanzânia, Centenário, Tobiatã e Mombaça, respectivamente.

O capim Tobiatã foi lançado pelo Instituto Agronômico de Campinas (IAC) com o intuito de fornecer ao mercado espécies de Panicum mais produtivas e adaptadas (Usberti Filho, 1982). Andrade (1987) comparando cultivares de Panicum obteve produções da ordem de $10,80 \mathrm{t}$ de MS/ha para um período de crescimento médio de 140 dias com o capim Tobiatã. Nesse experimento, as produções do capim Tobiatã não diferiram estatisticamente daquelas do Colonião (11,53 t) e do cultivar K-187 B (10,94 t). Boyer (1977) estudando dois cultivares de P. maximum e seis gramíneas tropicais obteve taxas de acúmulo de matéria seca da ordem de 83,50 a 192,00 kg/hadia, correspondentes a produções de 15,0 a 34,5 t MS/ha em 180 dias de crescimento.

A sazonalidade das gramíneas do gênero Panicum é acentuada, sendo considerada portanto uma forrageira de verão. Valores de 22,29 e $30 \%$ da produção anual foram obtidos durante a seca para os cultivares Tanzânia 1, Tobiatã e Mombaça, 
respectivamente (Jank, 1994). Pedreira \& Mattos (1981), comparando 25 espécies de gramineas tropicais, relataram a grande diferença entre as taxas de crescimento diário na época das águas e da seca. O pico da taxa de acúmulo de matéria seca ocorreu em dezembro, sendo que, a média de produção dos três cultivares de Panicum estudados foi de 73,60 kg MS/ha.dia. Gomide et al. (1979), estudando o capim Colonião, observaram a grande influência de fatores, tais como, nivel de adubação ( $25 \mathrm{~kg}$ de $\mathrm{N}$ e $30 \mathrm{~kg}$ de $\mathrm{K}_{2} \mathrm{O} / \mathrm{ha}$ a cada 28 dias x sem adubação) e idade da planta (14 a 98 dias de crescimento livre) nas taxas de acúmulo de matéria seca. Foi constatado um decréscimo nas taxas de crescimento após os 35 dias de rebrota e efeito positivo da adubação sobre essa variável.

Pinto et al. (1994a) afirmam que o aumento da produção de matéria seca em gramineas é função do peso de cada perfilho e da densidade de perfilhos numa dada área. Alguns autores sugerem a densidade de perfilhos como principal fator responsável pela produção de biomassa na pastagem, salvo durante a fase reprodutiva ou quando já houve estabilização da população de perfilhos para uma dada disponibilidade de fatores de crescimento (Nelson \& Zarrough, 1981).

O sucesso das estratégias de manejo depende também do número de perfilhos produzidos. Gramíneas perenes possuem dois tipos de perfilhos: basais, providos de sistema radicular, e aéreos, que se desenvolvem das gemas axilares dos colmos (Loch, 1993, citado por Nabinger \& Medeiros, 1995). Andrade (1987) demonstrou a variabilidade da dinâmica de perfilhamento entre cultivares do gênero Panicum. O número médio de perfilhos foi maior para o capim Tobiatã (344 perfilhos $/ \mathrm{m}^{2}$ ) do que para os cultivares Colonião (296 perfilhos $\left./ \mathrm{m}^{2}\right)$ e K-187 (282 perfilhos $\left./ \mathrm{m}^{2}\right)$. Já em relação 
ao peso médio dos perfilhos, o Colonião foi superior. Valores médios de 7,$42 ; 6,38 \mathrm{e}$ $5,25 \mathrm{~g}$ de matéria seca por perfilho foram encontrados nos cultivares Colonião, K-187 B e Tobiatã, respectivamente. Neste experimento, notou-se também que com maiores períodos de crescimento o aumento de produção de matéria seca se deu mais pelo aumento do peso dos perfilhos, do que pela sua densidade. Durante a fase reprodutiva as gramíneas cessam a multiplicação de perfilhos, elevando somente o peso destes. Nesse momento observa-se o alongamento dos entrenós e emergência da inflorescência (Nabinger \& Medeiros, 1995). Em pastejos mais intensos há tendência de se aumentar a densidade de perfilhos. Estudando o capim elefante, Corsi (1972) observou um maior perfilhamento da planta sob cortes de 0 a $5 \mathrm{~cm}$ do solo comparados com os de 15 a 20 $\mathrm{cm}$. A densidade de perfilhos também é aumentada por doses crescentes de nitrogênio (Nelson \& Zarrough, 1981).

Assim, o manejo das gramíneas tropicais deve ter como meta a obtenção de rebrotas vigorosas no menor tempo possível após o pastejo, através de aumento da densidade de perfilhos e do crescimento da biomassa por perfilho (Corsi et al., 1994).

\subsection{Eficiência de colheita das pastagens}

A forragem disponível numa determinada pastagem pode ter destinos diversos em função do manejo empregado sobre ela. Pode ser ingerida pelo animal em pastejo, cumprindo seu papel de fonte de nutrientes para o herbívoro; pode ser deixada como resíduo pós-pastejo para que contribua com a captação de luz e fotossíntese, necessária para início da subsequente rebrota; e finalmente pode ser totalmente perdida seja através 
do pisoteio, contato com dejeções animais ou pela senescência do tecido vegetal (Hillesheim, 1987).

As práticas de manejo de pastagem devem também visar a maximização do consumo de MS/área, reduzindo ao máximo possíveis perdas de forragem e material remanescente, sem no entanto prejudicar a perenidade ou a produtividade animal dessa pastagem (Hodgson, 1990; Humphreys, 1991 ).

Combellas \& Hodgson (1979) observaram uma redução na eficiência de pastejo de azevém perene, ou seja, na proporção consumida da matéria seca disponivel da forragem ( 85,49 e $33 \%)$, à medida que a disponibilidade de forragem/animal aumentou (30, 60 e $90 \mathrm{~g} \mathrm{MS} / \mathrm{kg}$ de PV, respectivamente), sendo a ingestão máxima de forragem por animal obtida com uma disponibilidade de forragem próxima ao dobro do consumo animal.

A disponibilidade de forragem/peso animal ( $\mathrm{kg} \mathrm{MS} / 100 \mathrm{~kg}$ de PV) é uma ferramenta de manejo que influi de forma significativa nas relações de produção, consumo e perda de forragem em uma pastagem. Numa determinada oferta de forragem por unidade de área (kg MS/ha), observam-se alterações significativas no desempenho animal quando a disponibilidade de forragem (\% PV) é modulada, com conseqüente variação da quantidade de resíduo pós-pastejo .

Aumentos na disponibilidade de forragem de modo geral, levam à redução na lotação e aumento do desempenho animal, elevando ou reduzindo a produtividade animal dependendo da sua magnitude. Stockdale \& King (1983) observaram em gramíneas temperadas um aumento do consumo de matéria seca de 1,8 para $2,9 \%$ do $\mathrm{PV}$ quando a 
disponibilidade de forragem/animal variou de 3,3 para 9,9\% do PV. Esses autores concluíram que o consumo atinge seu máximo quando a oferta de forragem é três vezes maior que a exigência. Em trabalho com Lolium multiflorum, Combellas \& Hodgson (1979), observaram um comportamento assintótico da relação entre disponibilidade de forragem/animal e o consumo de matéria seca. À medida que a disponibilidade aumentou (3, 6 e 9\% PV) o consumo individual também aumentou $(2,29 ; 2,66$ e 2,69 \% PV, respectivamente) com significativo aumento na produção de leite/animal.dia.

Hillesheim (1987) concluiu que as perdas de forragem em capim elefante são determinadas por diferentes variáveis. A cada $1 \mathrm{~cm}$ de elevação na altura do meristema apical da forragem, houve uma perda de $49,4 \mathrm{~kg}$ de matéria seca a mais no pastejo. Já a quantidade de folhas do material foi inversamente correlacionada com as perdas, reduzindo-se em $470 \mathrm{~g}$ MS/ha a cada $1 \%$ de aumento de folhas na planta toda. Da mesma forma, nesse trabalho o resíduo pós-pastejo aumentou (2680, 5460 e $4902 \mathrm{~kg} \mathrm{MS} / \mathrm{ha})$ à medida que a disponibilidade de forragem/animal foi aumentada $(4,8$ e $12 \% \mathrm{PV}$, respectivamente). Holmes \& Wilson (1984) afirmam que o resíduo pós-pastejo tem grande interferência sobre o consumo e sobre o desempenho animal. Esses autores comentam também haver uma relação assintótica entre consumo e resíduo pós-pastejo.

\subsection{Valor nutritivo da forragem sob pastejo}

O baixo consumo de energia digestível é a maior limitação na obtenção de altas produções de leite com animais sob regime de pasto, devido à baixa densidade energética 
que as forrageiras apresentam quando são colhidas com maturidade avançada (Minson, 1980). Burton (1970) atribui o descrédito no potencial produtivo das forragens tropicais à manejos impróprios a que são submetidas, principalmente em relação a níveis de reposição de nutrientes, intensidade e freqüência de desfolha.

Segundo Corsi (1988), o potencial elevado de produção de matéria seca por área das forragens tropicais e a homogeneidade da idade cronológica de seus perfilhos fazem com que estas percam muito rapidamente qualidade com a maturidade, assim como que elevem a sua relação haste/folha, o que acarreta em um menor consumo e decréscimo de seu valor alimentício quando colhidas em época imprópria. Gomide \& Zago (1982) observaram valores de 63,$0 ; 66,1$ e $53,0 \%$ de digestibilidade in vitro da matéria seca (DIVMS) do capim Colonião cortado com idades de rebrota de 21,28 e 63 dias, respectivamente.

Pinto et al. (1994a) salientaram a importância da relação haste/folha como fator de tomada de decisão no manejo de gramíneas tropicais e em sua qualidade. Eles observaram um aumento da relação haste/folha de $P$. maximum cv. Guiné à medida em que a idade de rebrota aumentava. Nas idades de $14,28,42,56$ e 70 dias observaram os valores de 0,$76 ; 0,82 ; 1,00 ; 1,49$ e 2,17 , respectivamente. Devido à menor digestibilidade das hastes em relação às folhas há uma tendência de maior rejeição do material disponivel à medida que a idade da planta avança. Da mesma forma, Andrade (1987) avaliando o capim Tobiatã encontrou relações haste/folha de 0,$5 ; 0,7 ; 0,76$ e 1,0 nas idades de 56,84 , 112 e 140 dias após o corte, respectivamente. 
Durante a fase reprodutiva há um aporte de fotoassimilados para a haste fazendo com que essa fração aumente. Pinto et al. (1994a) consideram como crítica relações haste/folha maiores que 1, utilizando esse parâmetro para definir uma freqüência máxima de corte para as gramíneas tropicais.

Euclides (1995) observou que o valor nutritivo de diferentes espécies de gramíneas tropicais apresentam variabilidade pequena, quando comparado ao efeito da maturidade dentro de cada genótipo. À medida que a planta tem seu estágio fisiológico adiantado, existe tendência de haver decréscimo da concentração de componentes de maior potencial de digestão (conteúdo celular) e aumento dos componentes da parede celular, com conseqüente queda da digestibilidade da forragem.

Estudando diversos cultivares de P. maximum, Euclides (1995) concluiu que valores de FDN inferiores a 55\% são raros. Valores superiores a $65 \%$ são comuns em tecidos novos e teores entre 75 a $80 \%$ são encontrados em materiais de maturidade avançada. No entanto o efeito desse componente parece estar mais correlacionado com características intrínsecas do que com seus valores absolutos (Van Soest, 1994).

Em capim Tobiatã, Andrade (1987) relatou um aumento dos componentes fibrosos da planta à medida que a sua idade avançou. Em relação ao FDN o autor observou valores de 68,$45 ; 77,85$ e $82,05 \%$, e para o FDA valores de 39,$35 ; 45,90$ e $56,60 \%$ nas idades de $28 ; 56$ e 84 dias de crescimento, respectivamente. Laredo \& Minson (1973) observaram que o consumo de hastes é menor que o de folhas mesmo quando sua composição bromatológica é semelhante. Esses autores determinaram uma necessidade maior de energia para degradar hastes de $P$. maximum, e atribuíram esse 
fato à dificuldade de quebra das ligações covalentes da lignina com os carboidratos estruturais da parede celular das hastes pelos microrganismos ruminais.

A porcentagem de parede celular nas forrageiras pode variar de 20 a $80 \%$ do seu peso seco. A qualidade alimentar da forragem em relação à parede celular pode ser analisada sob três aspectos: (a) proporção de parede celular (FDN) na matéria seca; (b) variação no arranjo espacial dessa fibra, relativo à anatomia da planta; e (c) composição química dessa parede e sua disponibilidade para o animal (Wilson, 1994). A digestibilidade da parede celular é variável numa amplitude média de 30 a $60 \%$. Este é um dos principais fatores que dificultam a quebra da fração fibrosa a um tamanho crítico ( $1 \mathrm{~mm}$ ) que permita sua saída do rúmen (Poppi et al., 1985, citados por Wilson, 1994).

Elevadas temperaturas ambientais reduzem a digestibilidade da parede celular. Fales (1986) observou que a elevação da temperatura ambiente durante o crescimento aumentou o conteúdo de parede celular em Festuca arundinacea e reduziu sua digestibilidade. Ford et al. (1979), em estudos com Panicum, obtiveram um aumento no conteúdo de FDN de 67 para $71 \%$ e aumento no teor de lignina, quando a temperatura de crescimento diurna/noturna foi elevada de $21 / 13$ para $32 / 24^{\circ} \mathrm{C}$. Akin et al. (1987), na tentativa de determinar as alterações anatômicas que ocorrem com a elevação da temperatura, observaram apenas aumento dos tecidos vasculares, havendo também elevação do teor de lignina no esclerênquima e no floema. No entanto, Fales (1986) não observou alteração do teor de lignina com o aumento da temperatura. Nesse contexto, Akin et al. (1987) sugerem que outros compostos fenólicos (ácidos p-cumárico e transferúlico) podem ser os responsáveis pela queda de digestibilidade com o aumento da 
temperatura. Aparentemente o ácido p-cumárico tem uma maior relação com a queda de digestibilidade, pois a relação p-cumário/trans-ferúlico aumentou de 0,64 para 0,93 quando a temperatura no crescimento de Festuca foi alterada de $13 / 10$ para $30 / 27{ }^{\circ} \mathrm{C}$ (diurna/noturna), respectivamente (Fales, 1986).

Ford et al. (1979) determinaram maiores correlações entre DIVMS e FDN, e DIVMS e lignina, em gramineas tropicais do que em temperadas. Da mesma forma, em gramíneas tropicais as correlações entre DIVMS e lignina aumentaram $(-0,58 ;-0,78$; $0,82)$ à medida que as temperaturas (diurna/noturna) de crescimento aumentaram (21/13; $27 / 19 ; 32 / 24^{\circ} \mathrm{C}$, respectivamente). Esses autores concluiram então que a temperatura de crescimento tem um fator deletério sobre a digestibilidade da forragem tropical, seja pela redução da digestibilidade dos componentes fibrosos ou pelo aumento do seu conteúdo. Dessa forma, podem ocorrer alterações de composição e qualidade de componentes fibrosos quando uma gramínea é desfolhada com freqüência fixa durante o período das águas, pois as temperaturas médias diárias são diferentes dentro desse período.

Akin (1989) lembra que a menor digestibilidade das gramíneas tropicais quando comparadas com as de clima temperado se deve principalmente à diferenças anatômicas e à temperatura a que são submetidas. Harris, 1990, citado por Wilson (1994) comenta que alguns tipos de células possuem apenas uma fina parede celular primária (mesófilo e floema) que não é lignificada. Por outro lado, os feixes vasculares e o esclerênquima têm parede celular espessa e lignificada, apresentando-se como uma barreira para a digestão no rúmen. 
As espécies $\mathrm{C}_{4}$ do gênero Panicum apresentaram em média apenas $50 \%$ de digestão dos tecidos parenquimatosos, enquanto as $\mathrm{C}_{3}$ tiveram $88 \%$ de DIVMS nesse mesmo tipo de tecido (Akin, 1989). A distribuição dos tecidos de baixa degradabilidade (esclerênquima e feixes vasculares) em Panicum maximum var. trichoglume são citados por Wilson (1993) como sendo $8 \%$ da lâmina foliar, $10 \%$ da nervura das folhas, $15 \%$ da bainha e $20 \%$ das hastes. Daí parte da explicação das diferenças de digestibilidade desses tecidos. Da mesma forma, tecidos de elevada degradação (mesófilo e parênquima) compõe $53 \%$ da lâmina foliar, $18 \%$ das nervura e apenas $4 \%$ da haste. Assim, pode-se inferir que o aumento da proporção de folhas na planta proporciona um aumento da qualidade da forragem disponível.

A lignina é o componente químico da parede celular que mais freqüentemente se correlaciona com baixas digestibilidades de forragens (Jung, 1989). No entanto, esse componente tem efeito somente sobre as frações da parede celular, não interferindo na disponibilidade dos nutrientes do protoplasma. A lignificação inicia quando o alongamento do órgão vegetal está completo. A indigestibilidade da lignina parece estar correlacionada com a relação de seus componentes guaiacil/siringil. As unidades de guaiacil teriam um efeito mais pronunciado sobre a digestibilidade devido ao tipo de ligação química que perfazem com a fibra (Van Soest, 1994). Jung \& Vogel (1986) estudando 194 amostras de forragem de oito diferentes espécies identificaram um aumento exponencial no conteúdo de lignina, à medida que o teor de FDN aumentou com a maturidade. 
Assim, conhecendo-se as características nutricionais das gramíneas tropicais e o efeito que o clima e o manejo exercem sobre elas, é possível delinear técnicas de pastejo que se adaptem a cada tipo de sistema de produção, em função de suas características de produtividade animal e vegetal (Euclides, 1995).

\subsection{Fluxo de tecidos e morfogênese em pastagens}

O desenvolvimento, crescimento e a senescência de folhas e perfilhos constituem os processos fisiológicos que caracterizam a dinâmica do desenvolvimento de uma pastagem. A manutenção da produtividade e da perenidade dependem da capacidade de reconstituição de tecido fotossintetizante após a desfolha. Essa capacidade é fruto de influência do meio, como clima, aspectos físicos e de manejo, além de fatores genéticos inerentes ao genótipo (Gomide, 1997).

A morfogênese estuda a origem e o desenvolvimento de diferentes órgãos de um organismo. Nabinger (1997), cita Chapman \& Lemaire, (1993), que descrevem a morfogênese das pastagens em crescimento vegetativo através de três características básicas: taxa de aparecimento de folhas, taxa de alongamento das folhas e duração de vida das folhas. A combinação dessas variáveis determina as principais características estruturais da pastagem: tamanho de folha, densidade de perfilhos e número de folhas vivas por perfilho. Considerando, portanto, que em uma forrageira específica há uma 
relação constante entre área e comprimento da folha, as três características citadas determinam o IAF.

O desenvolvimento vegetativo das gramíneas se faz pelo aparecimento e desenvolvimento de folhas e perfilhos, alongamento do colmo e crescimento do sistema radicular; depende portanto do desenvolvimento individual de cada fitômero (unidade fundamental da gramínea), constituído de nó, entre-nó, gema, lâmina e bainha (Moore \& Moser, 1995).

Inicialmente, os primórdios foliares são formados, crescem e se diferenciam em folhas de cada lado do meristema apical. As folhas alongam-se por dentro do pseudocolmo, estrutura formada pelas bainhas de folhas mais velhas, até aparecerem no perfilho. O intervalo de tempo entre o aparecimento de duas folhas consecutivas é chamado de filocrono. Por aparecimento entende-se a visualização da folha sem qualquer dessecação, manipulação ou interferência no perfilho. O tempo entre os eventos não tem necessariamente uma conotação cronológica, podendo utilizar-se como referência o tempo térmico (graus-dia) ou unidades fototérmicas (Wihelm \& McMaster, 1995). O filocrono pode ser influenciado por diversos fatores: temperatura (Collins \& Jones, 1988); genótipo (Pinto et al., 1994b); nutrientes (Vine, 1983) estação do ano (Barbosa et al., 1996) e intensidade de desfolha (Grant et al., 1981). Kniry et al. (1991) demonstraram que outros fatores tais como, disponibilidade de água e nutrientes, fotoperíodo e reservas de carboidratos têm um efeito menos expressivo que a temperatura na determinação do filocrono. 
O filocrono não é reflexo somente da taxa de iniciação dos primórdios foliares (plastocrono), pois dois outros fatores o influenciam: a taxa de alongamento de folhas e o comprimento da bainha foliar que envolve o colmo. Quanto menor a taxa de crescimento e maior o comprimento da bainha, maior será o filocrono.

A taxa de alongamento de folhas depende do comprimento da zona de alongamento e das taxas de alongamento nos diversos pontos dessa zona. Esses parâmetros por sua vez dependem da taxa de produção das células da epiderme, da sua taxa de alongamento e da duração do período de alongamento (Skinner \& Nelson ,1995). Todos esses fatores são influenciados por agentes genéticos e ambientais. As zonas de crescimento são um poderoso dreno metabólico chegando a concentrar até $78 \%$ de todos carboidratos não estruturais da planta (Allard \& Nelson, 1991).

O inverso do filocrono estima a taxa de aparecimento de folhas (Gomide, 1997), sendo que esta também pode ser definida em termos de unidades térmicas acumuladas entre a emergência de folhas consecutivas (Baker et al., 1980).

Miglietta (1991) e Skinner \& Nelson (1994) encontraram um aumento constante no filocrono à medida que a idade da planta avançou. Possivelmente, com o aumento em comprimento da bainha foliar, a folha demora mais para tornar-se visivel. Outra possibilidade seria um aumento gradual no filocrono devido ao aumento no plastocrono, à medida que a planta avança em idade. Skinner \& Nelson (1994) encontraram um aumento do filocrono para a formação das folhas de Festuca de 80 GD nas folhas mais novas para $160 \mathrm{GD}$ nas mais velhas. Observaram ainda que, a relação entre filocrono e a somatória térmica acumulada apresentava comportamentos diferentes a partir de 500 GD 
de tal modo que, sugeriram equações com diferentes coeficientes angulares para cada fase.

Medidas totalmente diferentes de filocrono são obtidas em função da metodologia utilizada. Por exemplo, quando calculado pelo índice de Haun (Haun, 1973) contra o tempo térmico, permite excelentes ajustes de dados; quando medido à cada folha, tem uma tendência de aumentar com o avanço de tempo.

A taxa de alongamento de folhas $(\mathrm{cm} /$ folha.dia) é um parâmetro morfológico de extrema importância para avaliação de gramíneas, devido a sua forte correlação com variáveis ligadas à produtividade dessas forrageiras. A expansão das folhas é responsável por $80 \%$ do seu crescimento, $95 \%$ do aumento de seu peso seco e $99 \%$ da área foliar (Hay \& Walker, 1989).

A taxa de alongamento de folhas é sensivel à mudanças de temperatura no meristema apical. Em gramíneas temperadas a taxa de alongamento de folhas responde de forma exponencial à temperatura média diária, quando esta se encontra entre 0 a $12{ }^{\circ} \mathrm{C}$ e de forma linear acima destes valores. Esse padrão de resposta ocorre até que sejam atingidos os valores ótimos do genótipo, entre 20 a $25{ }^{\circ} \mathrm{C}$ no caso dessas forrageiras (Nabinger,1997) e muda rapidamente do estádio vegetativo para o reprodutivo (Peacock, 1975), sendo maior nesse último numa dada temperatura (Gastal et al., 1992).

Kemp \& Blacklow (1982) comentaram que para gramíneas temperadas a taxa de alongamento de folhas pode ser descrita por uma equação quadrática em função da temperatura próxima ao ponto de crescimento. Assim, existe uma temperatura de crescimento máximo acima ou abaixo da qual há uma taxa constante de decréscimo de 
crescimento. Para o trigo (Triticum aestivum cv. Gamenya) esses autores encontraram uma temperatura ótima por volta de $28,5^{\circ} \mathrm{C}$ quando a velocidade de alongamento foi máxima (1,0 a 2,6 mm/dia).

Estudando o efeito da freqüência de corte e de doses de nitrogênio sobre o alongamento das folhas de azevém perene, Pearse \& Wilman (1984) observaram que à medida em que o intervalo de corte aumentou $(1,2,3$, e 4 semanas), a taxa de alongamento sofreu acréscimos em níveis decrescentes $(6,7 ; 7,8 ; 9,0$ e $9,5 \mathrm{~mm} / \mathrm{dia})$, respectivamente. A adubação nitrogenada ( $0 ; 66$ e $132 \mathrm{~kg} \mathrm{~N} / \mathrm{ha})$ aumentou claramente as taxas de alongamento (4,2; 8,0 e 12,5 mm/dia, respectivamente). Radin \& Boyer (1982) observaram uma queda de $75 \%$ da taxa de alongamento de folhas quando o teor de nitrogênio das mesmas foi reduzido em 33\%. Gastal \& Nelson (1994) atribuem esse fato ao maior acúmulo de nitrogênio na zona de alongamento da folha, especificamente na região da divisão celular.

A intensidade de pastejo também influencia o alongamento foliar. Estudando o efeito de três alturas de pastejo $(3,6$ e $9 \mathrm{~cm})$ com ovinos sobre azevém (Lollium perene) e trevo branco (Trifolium repens), Parsons et al. (1991) observaram que as maiores alturas de pastejo estiveram correlacionadas com menores taxas de alongamento de folha. Chapman et al. (1983) relatou um aumento no alongamento de folhas de trevo branco em pastejo rotacionado quando comparado com pastejo contínuo de carga variável. Davies (1974) em estudo com gramíneas temperadas, observou que apenas em pastejos muito severos (remoção de todas as folhas do perfilho) houve redução na taxa de alongamento em cerca de até $17 \%$; ressaltando assim a importância do meristema apical como dreno 
metabólico durante a expansão de folhas. Desfolhas de duas a três folhas em azevém perene não influenciaram na alongamento foliar (Davies, 1988).

A ação da temperatura sobre parâmetros morfogênicos de crescimento foliar de gramíneas temperadas depende de um determinismo genético. De forma geral, o efeito da temperatura sobre a taxa de alongamento de folhas é mais expressiva (exponencial) do que sobre a taxa de aparecimento de folhas (linear). Assim, observa-se maiores comprimentos de folha com o aumento da temperatura (Lemaire, 1985 citado por Nabinger, 1997).

A maior força causadora da expansão celular é a pressão de turgor, e essa é dependente do potencial osmótico da célula vegetal (Gastal \& Nelson, 1994). Esses autores apoiam a teoria de que a taxa de alongamento aumenta com o aumento da temperatura em função da alteração no metabolismo celular.

Corsi et al. (1994) em trabalho com gramíneas do gênero Brachiaria, determinaram o número de folhas em expansão durante a primavera e o verão. Encontraram valores de 1,79 e 1,73 (B. brizantha), 1,50 e 1,76 (B. humidicola) e 1,78 e 1,64 folhas em expansão por perfilho (B.decumbens), confirmando o efeito do genótipo e do ambiente sobre essa variável.

A senescência e morte de folhas é um processo parcialmente definido por controle genético e caracterizado por redução nos teores de constituintes do conteúdo celular (Davies, 1988), sendo que outros fatores como sombreamento, disponibilidade de nutrientes, água e doenças também influem em sua intensidade (Thomas \& Stoddart, 1980). 
Uma redução significativa na eficiência de pastejo e no consumo animal é observada quando herbivoros são submetidos ao pastejo em um relvado com taxa elevada de material morto e hastes (Michell \& Fulkerson, 1987). O primeiro sinal visível de senescência é o sintoma de amarelecimento das folhas, devido a redução no teor de clorofila. Dessa forma, outros pigmentos ficam mais visiveis tais como as xantofilas e os carotenos (Salisbury \& Ross, 1978).

Davies (1974) estudando forrageiras de clima temperado observou que as folhas mais recentemente expandidas competem com as mais velhas por luz, nutrientes e assimilados, o que resulta na manutenção de um número relativamente constante de folhas por perfilho. Dessa forma, diversos autores determinaram o número de folhas que um determinado genótipo é capaz de manter em cada perfilho. Robson (1973) constatou que a Lolium perene tem a capacidade de manter 3 folhas verdes por perfilho, a Dactylis glomerata por sua vez mantém 7 folhas verdes por perfilho (Calviere \& Duru, 1995) e estudando diversas espécies de brachiárias, Corsi et al. (1994), observaram que as as espécies do gênero Brachiaria tiveram condição de suportar de 5 a 7 folhas verdes por perfilho em função do genótipo.

De modo geral a quantidade de material senescido aumenta conforme diminui a freqüência entre cortes numa dada condição. Em capim elefante, Carvalho \& Damasceno (1996), observaram que a partir da quinta semana pós colheita iniciaram-se as primeiros sinais de senescência, que aumentou até a décima semana.

Pearse \& Wilman (1984) observaram em Lolium perene que com a redução da freqüência de colheita $(1,2,3$ e 4 semanas) havia um aumento da taxa de senescência 
$(3,5 ; 3,2 ; 4,1 ;$ e $7,9 \mathrm{~mm} /$ dia) e alteração também do acúmulo líquido de forragem $(3,2$; 4,$6 ; 4,9 ;$ e $1,4 \mathrm{~mm} /$ dia). Por outro lado, o efeito da adubação nitrogenada (0; 66 e $132 \mathrm{~kg}$ $\mathrm{N} / \mathrm{ha}$ ) propiciou acúmulo crescente de tecido vivo $(1,1 ; 3,2$ e $6,3 \mathrm{~mm} / \mathrm{dia})$, mesmo tendo acelerado também a taxa de senescência $(3,1 ; 4,8$ e 6,2 $\mathrm{mm} /$ dia $)$. Esses autores atribuíram tal fato ao aumento mais que proporcional da taxa de alongamento de folha, devido à maior disponibilidade de nitrogênio.

Fatores que aumentam a produção de ácido abscísico nas folhas, tais como deficiências de água e de nutrientes, parecem acelerar a senescência (Salisbury \& Ross, 1978). Monteiro et al. (1994) observaram que em Brachiaria brizantha cv. Marandú houve maior velocidade de senescência de folhas quando da omissão dos nutrientes nitrogênio e potássio, sendo a resposta mais intensa para o primeiro. Os valores foram de 0,$25 ; 1,35$ e 1,5 folhas senescidas para os grupos controle, sem potássio e nitrogênio.

Em pastagens colhidas de forma intermitente, durante o período de ausência da ação do animal, a taxa de acúmulo de carbono é devida ao balanço entre a produção de matéria seca bruta dos tecidos foliares e da senescência e perda de folhas. Imediatamente após uma desfolha severa, como no sistema de pastejo rotacionado, praticamente não ocorre morte de folhas. Mais tarde as primeiras folhas a morrer serão as presentes no início da rebrota. Assim, a taxa de acúmulo líquido de biomassa se aproxima de zero, à medida em que a taxa de senescência se iguala à de crescimento (Lemaire, 1997). As folhas das gramíneas de um modo geral têm uma determinada duração de vida em função da espécie. Para o azevém perene esse valor é aproximadamente 330 GD dia e corresponde ao tempo de aparecimento de três folhas. Em Festuca arrundinacea por sua 
vez a duração de vida da folha é de 570 GD dia e refere-se ao aparecimento de 2,5 folhas no perfilho principal. Esse autor adverte ao fato de que a taxa de senescência e a duração de vida das folhas obtidas em forragens cortadas de forma seqüencial deve ser avaliada e utilizada com cautela, pois esses parâmetros são sensíveis à freqüência de corte ou desfolha. 


\section{MATERIAL E MÉTODOS}

\subsection{Caracterização do local}

Este trabalho foi realizado numa área de 3,3 ha estabelecida com capim Tobiatã (Panicum maximum cv. Tobiatã) no ano de 1992, nas dependências do Sistema de Produção de Leite da "Fazenda Canchin" (CPPSE-EMBRAPA), municipio de São Carlos, Estado de São Paulo. As coordenadas do local são: latitude $22^{\circ} 01^{\prime} \mathrm{S}$, longitude $47^{\circ} 53^{\prime} \mathrm{W}$ e altitude de $854 \mathrm{~m}$ acima do nível do mar.

\subsection{Características químicas do solo e adubação}

No dia 20 de outubro de 1995 o capim foi submetido a um corte de uniformização. Recebeu em seguida adubação de $50 \mathrm{~kg}$ de N/ha, $50 \mathrm{~kg}$ de $\mathrm{P}_{2} \mathrm{O}_{5} / \mathrm{ha}$ e 50 $\mathrm{kg}$ de $\mathrm{K}_{2} \mathrm{O} / \mathrm{ha}$, na forma de uréia, super fosfato simples e cloreto de potássio, respectivamente. O primeiro pastejo foi realizado no dia 23 de novembro de 1995 . A análise química da amostra de solo da área experimental pode ser observada no Quadro 1. 
Quadro 1. Características químicas do solo (0 a $20 \mathrm{~cm}$ ) da área experimental.

\begin{tabular}{cccccccccc}
\hline $\mathrm{pH}^{(1)}$ & $\begin{array}{c}\mathrm{MO} \\
\%\end{array}$ & $\begin{array}{c}\mathrm{P}^{(2)} \\
\mathrm{Ppm}\end{array}$ & $\mathrm{Ca}$ & $\mathrm{K}$ & $\mathrm{Mg}$ & $\mathrm{Al}$ & $\mathrm{H}$ & $\mathrm{CTC}$ & $\mathrm{V}$ \\
& meq $/ 100 \mathrm{~cm}^{3}$ & & & & & $\%$ \\
\hline 6,1 & 2,4 & 46 & 2,9 & 0,2 & 1,4 & 0 & 2,0 & 6,5 & 69 \\
\hline
\end{tabular}

${ }^{1} \mathrm{Em} \mathrm{CaCl}_{2}$

${ }^{2}$ Fósforo em extrator resina

\subsection{Manejo da pastagem e dos animais}

A área foi dividida em 34 piquetes de aproximadamente $920 \mathrm{~m}^{2}$, sendo reservados cerca de $1700 \mathrm{~m}^{2}$ para área de descanso dos animais e corredores de acesso aos piquetes. O período de ocupação de cada piquete foi de um dia, sendo então novamente pastejado após 33 dias de descanso, conforme as orientações de manejo de Santos (1993). O manejo consistia em dar acesso inicialmente ao lote de vacas de maior produção de leite do rebanho (Lote A), os quais permaneciam no piquete das 19 h00 às 04h30. No restante do dia esses animais tinham acesso à uma área distinta reservada para descanso à sombra. Por volta das $07 \mathrm{~h} 00$ o piquete em questão recebia o lote de repasse que era composto por diversas categorias animais, tendo como único objetivo consumir os extratos inferiores do pasto até uma altura de resíduo de aproximadamente $40 \mathrm{~cm}$. A carga animal do Lote A era ajustada de forma a permitir uma sobra de forragem para o repasse, avaliada visualmente como de praxe, pelos funcionários do sistema de produção 
de leite. O lote de repasse variava em tamanho de acordo com a quantidade diária de sobra.

No dia seguinte à cada pastejo o piquete recebia adubação de $85 \mathrm{~kg}$ de $\mathrm{N}$ e 85 $\mathrm{kg}$ de $\mathrm{K}_{2} \mathrm{O} /$ ha por pastejo, na forma de uréia e cloreto de potássio, resultando numa adubação média de $430 \mathrm{~kg}$ de N/ha e $430 \mathrm{~kg}$ de $\mathrm{K}_{2} \mathrm{O} / \mathrm{ha}$, aplicados durante a estação de pastejo.

O manejo de alimentação dos animais do Lote A foi baseada portanto, em pastejo de capim Tobiatã e fornecimento de concentrado nos horários após ordenha (06h00 e 18h00), na proporção média de um quilo de concentrado para cada 2,8 litros de leite produzido. Esse concentrado era composto de $65 \%$ de milho grão moído, $30 \%$ de farelo de soja, $1 \%$ de uréia e $4 \%$ de suplemento mineral.

\subsection{Dados climáticos}

Os dados climáticos correspondentes ao período experimental foram obtidos no Centro de Pesquisa de Pecuária do Sudeste (CPPSE) - EMBRAPA de São Carlos e estão ilustrados no Quadro 2. 
Quadro 2. Dados climáticos e estimativa de acúmulo de GD do local do experimento, durante o período de outubro de 1995 a maio de 1996.

\begin{tabular}{cccccc}
\hline Mês & $\begin{array}{c}\text { Acúmulo } \\
\text { Médio de GD }\end{array}$ & $\begin{array}{c}\text { Precipitação } \\
\mathrm{mm} / \text { dia }\end{array}$ & \multicolumn{3}{c}{ Temperatura Diária $\left({ }^{\circ} \mathrm{C}\right)$} \\
\cline { 4 - 6 } & & & $\begin{array}{c}\text { Média } \\
\text { Máxima }\end{array}$ & $\begin{array}{c}\text { Média } \\
\text { Mínima }\end{array}$ & Média \\
\hline Outubro 1995 & 11,5 & 137,2 & 27,2 & 15,7 & 21,5 \\
Novembro 1995 & 12,5 & 114,2 & 28,2 & 16,8 & 22,5 \\
Dezembro 1995 & 13,0 & 134,2 & 28,0 & 18,1 & 23,0 \\
Janeiro 1996 & 13,9 & 358,0 & 28,8 & 19,0 & 23,9 \\
Fevereiro 1996 & 14,4 & 215,5 & 29,6 & 19,1 & 24,4 \\
Março 1996 & 13,4 & 171,8 & 28,6 & 18,3 & 23,4 \\
Abril 1996 & 11,9 & 71,0 & 27,5 & 16,2 & 21,9 \\
Maio 1996 & 8,8 & 40,5 & 24,4 & 13,2 & 18,8 \\
\hline
\end{tabular}

${ }^{1}$ Estimado através da fórmula $\mathrm{GD}=((\operatorname{Tmáx}+\mathrm{Tmin}) / 2)-10^{\circ} \mathrm{C}$

\subsection{Variáveis avaliadas}

Em 150 perfilhos escolhidos ao acaso foram medidas a taxa de alongamento de folhas e a renovação de tecidos, 75 perfilhos para cada tipo de medida. Os perfilhos foram alocados em 10 parcelas $\left(92 \mathrm{~m}^{2}\right)$, com cinco perfilhos cada, dentro de três dos 34 piquetes existentes no sistema. Dessa forma 50 perfilhos foram acompanhados por piquete, durante diferentes fases do crescimento da forrageira. Os perfilhos eram identificados por cinco diferentes cores, através de uma fita plástica presa à sua base.

A taxa de alongamento de folhas foi medida de forma que cada folha tinha seu comprimento medido de sua extremidade até a lígula exposta da segunda folha anterior à ela no perfilho. A folha era dada como totalmente expandida quando duas medidas de 
comprimento consecutivas se repetiam. As medidas eram feitas a cada 2 ou 3 dias a partir de 8 a 10 dias após o pastejo como sugere Gastal et al. (1992).

A renovação de tecidos foi observada nos mesmos períodos da taxa de alongamento e consistia em avaliar visualmente o número de folhas totalmente expandidas (lígula perfeitamente visível), folhas em expansão e folhas senescentes. A partir de cada nova medida de um piquete, as folhas anteriormente senescentes eram descartadas da contagem e fazia-se uso da marcação da folha verde mais velha com tinta não tóxica, para que a longevidade dessa fosse medida.

O filocrono e a taxa de aparecimento de folhas (inverso do filocrono), foram calculados como a relação entre o período da avaliação, em dias ou em GD, e o número de folhas que apareciam nesse tempo. Os graus-dia foram calculados da seguinte forma: $\mathrm{GD}=(T \operatorname{máx}+T \min ) / 2-10{ }^{\circ} \mathrm{C}$, onde: Tmáx e Tmin são as temperatura máximas e mínimas diárias registradas no período de avaliação, respectivamente.

Aproximadamente a cada 17 dias foram feitas avaliações da produção e da qualidade da forragem, em dois piquetes diferentes dos utilizados para avaliar o fluxo de tecidos, onde foi medido:

- Disponibilidade de MS (planta toda e resíduo pós-pastejo): Imediatamente antes da entrada dos animais no piquete a ser amostrado (planta toda) e no dia seguinte à saída do lote de repasse (resíduo pós-pastejo), toda forragem cuja base da touceira estivesse contida em quatro amostras retangulares de $3 \mathrm{~m}^{2}(\operatorname{lm} \times 3 \mathrm{~m})$, escolhidas ao acaso pelo método das linhas de intercessão, foi cortada o mais rente possível do solo ( 3 a $4 \mathrm{~cm})$ e coletada para posterior pesagem (Adaptado de Hillesheim, 1987). 
- Fracionamento da planta: A partir de cada amostra de produção e resíduo uma subamostra de aproximadamente 3 a $4 \mathrm{~kg}$ foi separada. Esse material coletado foi separado em lâminas foliares, denominadas apenas como fração "folhas"; colmo e bainha foliar, denominados de fração "haste"; e material senescente para posterior secagem em estufa a $60^{\circ} \mathrm{C}$ por 72 horas e definição das relações entre os componentes com base na matéria seca.

- Altura da planta: A altura da forragem no momento de entrada dos animais (planta toda) assim como a da sua saída (resíduo pós-pastejo) foi tomada em dez pontos aleatórios. A variável altura consistiu no comprimento medido desde o nível do solo até a curvatura da última folha completamente expandida.

- Densidade da forragem: Foi calculada dividindo-se a disponibilidade de MS (kg/ha) estimada no perfil da planta toda e do resíduo pós-pastejo pela altura da planta $(\mathrm{cm})$.

- Perda de forragem: Foram marcadas quatro áreas de $4 m^{2}(2 m \times 2 m)$ em diferentes locais dos dois piquetes. Logo após o seu pastejo, cada área era cuidadosamente limpa de todo material caído deixando-se o solo exposto. Após o fim do pastejo subseqüente, todo o material caído nessas áreas foi coletado e seco em estufa a $60^{\circ} \mathrm{C}$ por 72 horas para posterior pesagem (Adaptado de Hillesheim, 1987).

- Taxa de lotação: Foi observada para o lote principal de vacas (Lota A) para cada período de pastejo. Convencionou-se padronizar a carga animal em "unidade animal" (UA), representada por um animal de $450 \mathrm{~kg}$ de peso. Dividindo-se a somatória do peso dos animais do lote pelo peso padrão da UA e dividindo-se pela área utilizada no período, obteve-se a taxa de lotação da pastagem. 
- Pastejo simulado: Anteriormente ao pastejo, dois amostradores fizeram uma coleta manual da forragem simulando a desfolha efetuada pelos animais do lote de ponta (Lote A), as amostras foram secas em estufa e destinadas à análise bromatológica (Le Du \& Penning , 1982).

- Análises bromatológicas: Cada uma das quatro sub-amostras da produção e do resíduo foram, após separadas em lâmina foliar (folha), colmo e bainha foliar (haste) e material senescente, secas a $60^{\circ} \mathrm{C}$ em estufa de circulação forçada de ar por um período de 72 horas. Esse material foi então moído em moínho tipo Wiley, em peneira de $1 \mathrm{~mm}$ de diâmetro, acondicionado em recipientes de vidro e devidamente estocado para realização de análises químicas segundo a Association of Official Analytical Chemists (AOAC), 1990: teor de matéria seca a $100^{\circ} \mathrm{C}$ por 24 horas e teor de proteína bruta por micro Kjeldahl. O teor de fibra insolúvel em detergente ácido (FDA), de fibra insolúvel em detergente neutro (FDN) e teor de lignina foram determinados segundo Goering \& Van Soest (1970). A digestibilidade in vitro verdadeira da matéria seca do pastejo simulado e das lâminas foliares da planta toda de acordo com de Tilley \& Terrey, 1963, adaptado por Goering \& Van Soest (1970).

Para uma mais fácil interpretação dos resultados as amostras foram agrupadas em cinco períodos:

1. Coletas dias $23 / 11 / 95$ e $27 / 12 / 95$

2. Coletas dias 13/01/96 e 30/01/96

3. Coletas dias $16 / 02 / 96$ e 04/03/96

4. Coletas dias 21/03/96 e 07/04/96 
5. Coletas dias 24/04/96 e 11/05/96

\subsection{Análise estatística}

As variáveis estudadas foram submetidas à análise de variância em relação ao período da estação de crescimento fazendo-se uso do recursos do pacote estatístico SAS (1985), através dos procedimento Proc GLM-SAS. 


\section{RESULTADOS e DISCUSSÃO}

\subsection{Produção, utilização e fracionamento da forragem}

A disponibilidade de forragem ( $\mathrm{kg} \mathrm{MS/ha.33dias)} \mathrm{antes} \mathrm{de} \mathrm{cada} \mathrm{pastejo}$ manteve-se estável dos períodos 2 a 5, apresentando um valor menor apenas no período inicial da estação de pastejo, embora no último período já houvesse uma tendência à redução dessa variável (Quadro 3). O valor médio de $12.473 \mathrm{~kg} \mathrm{MS} /$ ha após um período de 33 dias de crescimento é bastante superior aos valores encontrados por Sarmento et al. (1997), que obteve disponibilidades de forragem de aproximadamente 5.500 a 9.900 kg MS/ha em pastagem de capim Tobiatã, ajustados para um ciclo de pastejo semelhante.

O resíduo pós-pastejo aumentou com o adiantar da estação de pastejo, refletindo uma distorção nos objetivos de manejo propostos inicialmente. Os valores referentes ao resíduo variaram de 1.491 a $8.089 \mathrm{~kg} / \mathrm{ha}$ do período 1 ao 4 , demonstrando que a eficiência de colheita estimada decaiu com o avançar da estação. Esse fato ocorreu mesmo com a utilização do lote de repasse, sendo que a cada período os animais em pastejo deixavam o capim Tobiatã numa maior altura de resíduo. 
Quadro 3. Variáveis relacionadas com a disponibilidade de MS da planta toda, resíduo pós-pastejo e perdas de pastejo.

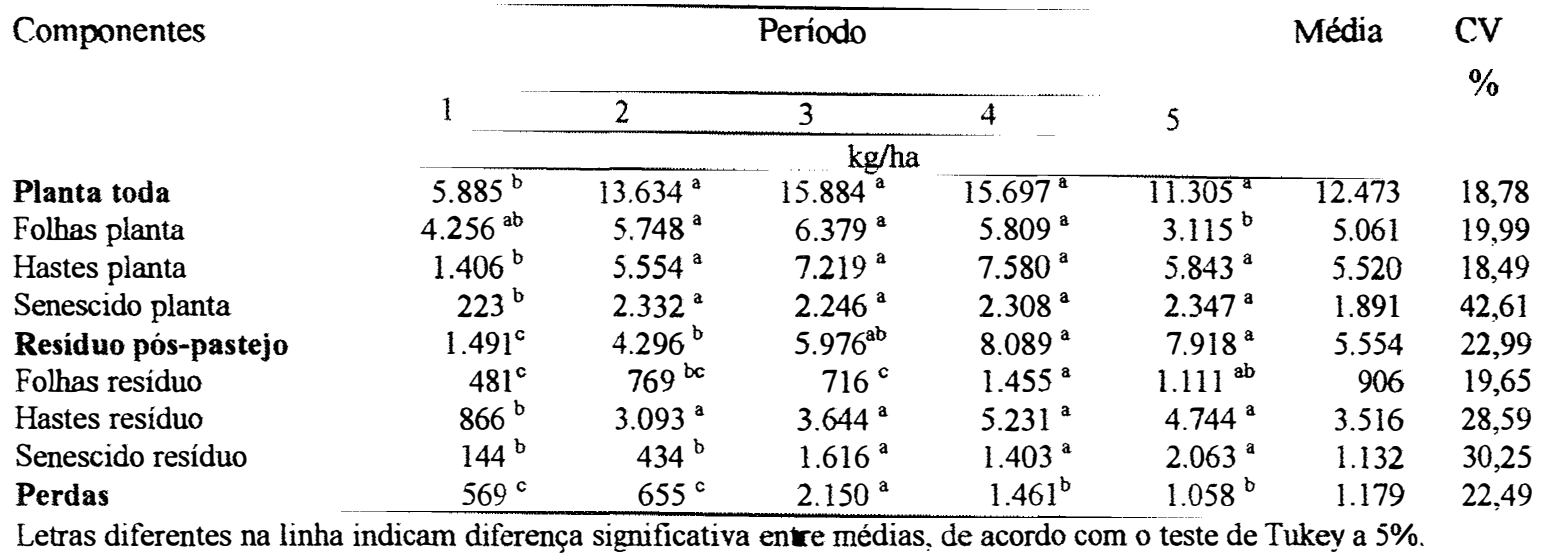

É interessante notar que a quantidade de folhas da planta toda comportou-se de forma inversa em relação à do resíduo pós-pastejo (Quadro 3). Enquanto a quantidade de folhas diminuiu na planta toda durante o final da estação de pastejo (período 5), no resíduo pós-pastejo essa fração aumentou, indicando uma menor colheita de tecidos vegetais de melhor qualidade nutricional, os quais já tinham sua disponibilidade total também reduzida. A quantidade de hastes no primeiro período foi menor do que nos demais, tanto na planta toda quanto no resíduo pós-pastejo. Para a planta toda e para o resíduo pós-pastejo, as médias da fração haste foram de 5.520 e $3.516 \mathrm{~kg} / \mathrm{ha}$, respectivamente.

A taxa de acúmulo diário de matéria seca para cada período foi estimada subtraindo-se da disponibilidade total de matéria seca da planta toda, o resíduo médio do período anterior. Dividiu-se então o valor obtido por 33 dias de crescimento (Quadro 4), seguindo o raciocínio proposto por Balsalobre (1996). A quantidade de material 
disponível após o corte de uniformização foi de $242 \mathrm{~kg}$ de MS/ha, sendo considerada no cálculo da taxa inicial de acúmulo de MS (período 1).

Considerando um período de 180 dias de utilização da forrageira durante a época de crescimento favorável e uma taxa média de acúmulo diário de MS de $256 \mathrm{~kg} / \mathrm{ha}$ (Quadro 4), ter-se-ia uma produção total de $46.080 \mathrm{~kg}$ de MS/ha. Se a esse valor for acrescida a quantidade média de resíduo pós-pastejo de $5.554 \mathrm{~kg} / \mathrm{ha}$, estimar-se-ia uma produção média total de $51.634 \mathrm{~kg}$ de MS/ha no periodo. Esse valor está muito próximo ao de $53.000 \mathrm{~kg} / \mathrm{ha}$ de MS citado por Jank (1994) como valor máximo obtido na avaliação de 156 acessos de Panicum moximum. Já Machado et al. (1997) observaram em capim Tobiatã, cortado a cada 35 dias no periodo das águas, produções de matéria seca verde total da ordem de 16.826 a $19.093 \mathrm{~kg} / \mathrm{ha} .180$ dias em função das alturas de corte de 40 e $20 \mathrm{~cm}$, respectivamente. No entanto as condições de fertilidade de solo e de adubação foram inferiores às do presente experimento.

As perdas de pastejo foram maiores nos três períodos finais de observação. Os valores encontrados foram de 569, 655, 2150, 1461 e $1058 \mathrm{~kg}$ MS/ha nos respectivos períodos. As perdas no período 3 foram significativamente maiores que nos demais, assim como nos períodos 4 e 5 os valores foram superiores aos dos períodos 1 e 2 que não apresentaram diferença entre si. Dessa forma, as perdas foram mais elevadas nos períodos onde a disponibilidade de MS, a altura da planta e as quantidades de hastes tenderam a ser maiores. Hillesheim (1987) observou que em capim elefante as perdas de pastejo foram menores, quanto maior a porcentagem de folhas na planta, quanto mais baixa a altura do seu meristema apical e quando as disponibilidades de MS total/animal (\% PV) 
foram menores. Esse autor encontrou em capim elefante sob pastejo rotacionado um valor médio de perda de forragem após o pastejo de $1.124 \mathrm{~kg} \mathrm{MS} / \mathrm{ha}$ durante o período das águas. Também estudando o capim elefante Balsalobre (1996) observou uma média de $1.973 \mathrm{~kg} \mathrm{MS} / \mathrm{ha}$ perdidos após o pastejo. Esses valores da literatura estão próximos dos $1.179 \mathrm{~kg}$ MS/ha obtidos como média do capim Tobiatã neste experimento. Possivelmente, as perdas decorrentes do pastejo no capim Tobiatã neste experimento, seriam minimizadas caso a planta fosse manejada em menor altura de resíduo e com maior proporção de folhas na MS.

As taxas de acúmulo tenderam a reduzir-se do período 3 em diante, seguindo a sazonalidade de produção de gramíneas tropicais descritas por Machado et al. (1997) e Pedreira \& Mattos (1981). Os valores obtidos para os cinco períodos de observação foram respectivamente de 171, 368, 350, 295 e $97 \mathrm{~kg} / \mathrm{ha}$.dia de MS (Quadro 4).

Quadro 4. Estimativa da dinâmica de utilização e acúmulo de MS da pastagem.

\begin{tabular}{lcccccc}
\hline Componente & \multicolumn{5}{c}{ Período } & Média \\
\cline { 2 - 6 } & 1 & 2 & 3 & 4 & 5 & \\
\hline $\begin{array}{l}\text { Taxa de acúmulo } \\
\text { MS (kg/ha.dia) }\end{array}$ & 171 & 368 & 350 & 295 & 97 & 256 \\
$\begin{array}{l}\text { Disponivel } \\
\text { (\% MS total) }\end{array}$ & 100 & 100 & 100 & 100 & 100 & 100 \\
$\begin{array}{l}\text { Resíduo pós-pastejo } \\
\text { (\% MS total) }\end{array}$ & 25,34 & 31,51 & 37,72 & 51,53 & 70,04 & 44,53 \\
$\begin{array}{l}\text { Perdas pós-pastejo } \\
\text { (\% MS total) }\end{array}$ & 9,67 & 4,80 & 13,57 & 9,31 & 9,36 & 9,45 \\
$\begin{array}{l}\text { Desaparecido } \\
(\% \text { MS total) }\end{array}$ & 65,00 & 63,69 & 48,71 & 39,16 & 20,60 & 46,02 \\
\hline
\end{tabular}

No Quadro 4 observa-se ainda que a eficiência média estimada de colheita (desaparecido) para o período experimental foi de $46,02 \%$. Durante o período 5 atingiu 
seu menor valor $(20,60 \%)$, enquanto no período inicial foi de $65 \%$. A eficiência de colheita em pastejo pode variar numa amplitude de 30 a $80 \%$, dependendo das condições de manejo à que a forrageira é submetida (Hillesheim, 1987). Esse mesmo autor observou em pastejo de capim elefante uma eficiência média de colheita de $37 \%$ do material disponível durante o período das águas, atribuindo esse fato à não eliminação do meristema apical da forrageira no primeiro pastejo. Balsalobre (1996) relatou uma eficiência de colheita média de $32,20 \%$ em capim elefante rotacionado sob ciclo de 46 dias, com disponibilidade de forragem média de $7,29 \% \mathrm{PV}$, sugere então que estudos sejam feitos para determinar o efeito da disponibilidade de forragem e da altura de resíduo sobre as perdas.

O baixo aproveitamento da pastagem possivelmente foi decorrente das elevadas disponibilidades de forragem que vigoraram durante o período experimental (Quadro 5). A disponibilidade de forragem média observada para o lote principal de vacas foi de 7,0 \% PV. Para que se obtenham produções animais satisfatórias, a literatura sugere que os valores de disponibilidade de forragem estejam ao redor de $6 \%$ PV (Combellas \& Hodgson, 1979). Esses autores observaram uma queda no aproveitamento da forragem à medida que a sua disponibilidade foi aumentada. $\mathrm{O}$ aproveitamento de azevém perene sob pastejo reduziu-se de 85 para $33 \%$ quando a disponibilidade aumentou de 3 para $9 \%$ PV. Balsalobre (1996) lembra que os estudos que definiram a disponibilidade de forragem de $6 \%$ PV como recomendável, tiveram ofertas de MS ( $t / h a)$ menores que as geralmente obtidas com gramíneas tropicais manejadas intensivamente. Consequentemente, os resíduos pós-pastejo observados nesses experimentos também foram inferiores. Portanto, 
ao se fixar um valor de disponibilidade de forragem (\% PV) para toda estação de crescimento, observa-se uma redução na eficiência da colheita, à medida em que a produção de biomassa de forragem aumenta. Dessa forma, Balsalobre (1996) adverte para que maior atenção seja dada no sentido de se considerar o resíduo pós-pastejo como norteador de manejo em pastagens tropicais, principalmente quando os valores de disponibilidade de matéria seca sejam superiores a $6.000 \mathrm{~kg} / \mathrm{ha}$.

Quadro 5. Variáveis relacionadas à componentes de pastejo e desempenho animal.

\begin{tabular}{|c|c|c|c|c|c|c|}
\hline \multirow[t]{2}{*}{ Item } & \multicolumn{5}{|c|}{ Período } & \multirow[t]{2}{*}{ Média } \\
\hline & 1 & 2 & 3 & 4 & 5 & \\
\hline $\begin{array}{l}\text { Taxa de lotação } \\
(\mathrm{UA} / \mathrm{ha})^{1}\end{array}$ & 12,57 & 10,65 & 14,27 & 10,49 & 11,46 & 11,89 \\
\hline $\begin{array}{l}\text { Disponibilidade de } \\
\text { MS }(\% \mathrm{PV})^{2}\end{array}$ & 3,4 & 8,4 & 7,1 & 9,8 & 6,3 & 7,0 \\
\hline $\begin{array}{l}\text { Produção leite } \\
\text { (kg/vaca.dia) }\end{array}$ & 30,9 & 35,9 & 31,2 & 27,2 & 28,0 & 30,6 \\
\hline Dias de lactação & 57 & 49 & 42 & 67 & 81 & 59 \\
\hline $\begin{array}{l}\text { Concentrado/leite } \\
(\mathrm{kg} / \mathrm{kg})\end{array}$ & 2,7 & 2,8 & 3,0 & 2,8 & 2,8 & 2,8 \\
\hline $\mathrm{ECC}^{4}$ & 2,9 & 2,8 & 2,9 & 2,8 & 2,9 & 2,9 \\
\hline
\end{tabular}

As disponibilidades de forragem que vigoraram neste experimento permitiram taxas de lotação de 10,49 a 14,27 UA/ha, com valores de desempenho animal que podem ser observados no Quadro 5. Níveis de produção médios de 30,6 litros/vaca.dia, com 59 dias de lactação e escore de condição corporal de 2,9 foram observados nos animais do lote A. Esses valores médios para o período experimental foram obtidos com animais 
tendo como dieta exclusiva pastejo de capim Tobiatã e concentrado fornecido na proporção média de $1 \mathrm{~kg}$ de concentrado para cada 2,8 litros de leite.

Com o avançar dos períodos de pastejo, a porcentagem total de folhas da planta toda reduziu de 72,32 para $27,55 \%$ (Quadro 6). Da mesma forma, a altura da forragem e a do resíduo elevaram-se com o aumento da disponibilidade de MS. A altura da planta variou entre 123 e 199,5 cm (Quadro 6) enquanto que a altura do resíduo pós-pastejo variou entre 57,83 a 140,25 cm (Quadro 7). A combinação dessas variáveis, reflexo das disponibilidades de forragem que vigoraram entre 3,4 e 9,8 \% PV (Quadro 5), sugerem também que o baixo aproveitamento e a elevada perda da forragem provavelmente seriam minimizados se o resíduo pós-pastejo fosse mantido mais baixo, ou seja, se a disponibilidade de forragem/animal (\% PV) fosse menor.

Quadro 6. Variáveis relacionadas com a produção e o fracionamento da planta toda.

\begin{tabular}{|c|c|c|c|c|c|c|c|}
\hline \multirow[t]{2}{*}{ Componentes } & \multicolumn{5}{|c|}{ Período } & \multirow[t]{2}{*}{ Média } & \multirow{2}{*}{$\begin{array}{r}\mathrm{CV} \\
\%\end{array}$} \\
\hline & 1 & 2 & 3 & 4 & 5 & & \\
\hline Altura $(\mathrm{cm})$ & $123,00^{c}$ & $175,75^{b}$ & $172,00^{6}$ & $199,50^{a}$ & $171,75^{b}$ & 168,40 & 3,35 \\
\hline $\begin{array}{l}\text { Densidade } \\
\text { (kg MS/ha.cm) }\end{array}$ & $47,85^{b}$ & $77,58^{a}$ & $92,12^{\mathrm{a}}$ & $78,68^{a}$ & $65,82^{a b}$ & 74,07 & 17,20 \\
\hline Haste/folha & $0,33^{\mathrm{d}}$ & $0,97^{\mathrm{c}}$ & $1,13^{b c}$ & $1,30^{b}$ & $1,88^{\mathrm{a}}$ & 1,09 & 14,38 \\
\hline Folhas na MS (\%) & $72,32^{\mathrm{a}}$ & $42,16^{\mathrm{b}}$ & $40,26^{b}$ & $37,01^{b}$ & $27,55^{\mathrm{c}}$ & 40,58 & 8,60 \\
\hline Hastes na MS (\%) & $23,89^{c}$ & $40,74^{b}$ & $45,56^{\text {ab }}$ & $48,29^{a b}$ & $51,69^{a}$ & 44,26 & 9,40 \\
\hline Senescente MS (\%) & $3,79^{b}$ & $17,10^{\mathrm{a}}$ & $14,18^{\mathrm{a}}$ & $14,70^{\mathrm{a}}$ & $20,76^{\mathrm{a}}$ & 15,16 & 30,16 \\
\hline
\end{tabular}

As frações da planta tenderam a tornar-se menos favoráveis à medida em que avançou a estação de pastejo. No Quadro 6 observa-se um aumento claro ocorrido na relação haste/folha do capim Tobiatã. Tal fato demonstra uma maior participação de 
tecidos de menor potencial de ingestão e digestão na planta. As hastes aumentaram sua participação relativa do primeiro $(23,89 \%)$ ao último período $(51,69 \%)$ de observação. A qualidade nutricional inferior das hastes foi constatada para diversas espécies de Panicum por Akin et al. (1984). Valores acima de 1,0 para a relação haste/folha, como os observados nos período 3, 4 e 5 (Quadro 6), foram considerados como limitantes ao consumo e desempenho animal por Pinto et al. (1994a).

A densidade média de forragem observada para o capim Tobiatã, observada no Quadro 6, foi de 74,07 kg MS/ha.cm. Baixas densidades de MS nas pastagens são um fator limitante ao consumo devido à dificuldade de apreensão da forragem pelo animal (Stobbs, 1973a). Nessa condição, o tempo de pastejo teria que ser aumentado para compensar menores volumes por bocado, fato que ocorre de forma limitada.

Quadro 7. Variáveis relacionadas com a produção e o fracionamento do resíduo póspastejo.

\begin{tabular}{|c|c|c|c|c|c|c|c|}
\hline \multirow[t]{2}{*}{ Componentes } & \multicolumn{5}{|c|}{ Período } & \multirow[t]{2}{*}{ Média } & \multirow{2}{*}{$\begin{array}{l}\mathrm{CV} \\
\%\end{array}$} \\
\hline & 1 & 2 & 3 & 4 & 5 & & \\
\hline Altura $(\mathrm{cm})$ & $57,83^{\circ}$ & $69,75^{c}$ & $97,75^{b}$ & $117,00^{a b}$ & $140,25^{\mathrm{a}}$ & 96,32 & 11,07 \\
\hline $\begin{array}{l}\text { Densidade } \\
\text { (kg MS/ha.cm) }\end{array}$ & $25,78^{b}$ & $61,59^{a}$ & $61,14^{\mathrm{a}}$ & $69,14^{\mathrm{a}}$ & $56,46^{\mathrm{a}}$ & 57,54 & 19,46 \\
\hline Haste/folha & $1,80^{b}$ & $4,02^{a b}$ & $5,09^{\mathrm{a}}$ & $3,60^{a b}$ & $4,27^{\mathrm{ab}}$ & 3,88 & 34,94 \\
\hline Folhas na MS (\%) & $32.26^{\mathrm{a}}$ & $17,90^{b}$ & $11,98^{b}$ & $17,99^{b}$ & $14,03^{b}$ & 16,32 & 22,19 \\
\hline Hastes na MS (\%) & $58,08^{a}$ & $72,00^{a}$ & $60,98^{a}$ & $64,67^{\mathrm{a}}$ & $59,91^{\text {a }}$ & 63,30 & 11,49 \\
\hline Senescente na MS $(\%)$ & $9.66^{b}$ & $10,10^{b}$ & $27,04^{\mathrm{a}}$ & $17,34^{b}$ & $26,05^{\mathrm{a}}$ & 20,38 & 27,42 \\
\hline
\end{tabular}

As frações do resíduo (Quadro 7), sofreram menores alterações com o decorrer dos períodos. A porcentagem de folhas do resíduo pós-pastejo no período $1(32,26 \%)$, 
foi significativamente superior aos demais, os quais não diferiram entre si. A densidade média do resíduo ( $\mathrm{kg}$ de MS/ha.cm) foi de 57,54 e a relação haste/folha de 3,88 , demonstrando a seletividade de colheita do material. As porcentagens das diferentes frações no resíduo foram de 16,$32 ; 63,30$ e $20,38 \%$ da MS para folhas, hastes e material senescente, respectivamente. No decorrer dos períodos de pastejo, não se observou um aumento nos valores relativos de haste no resíduo, no entanto a porcentagem de material senescente foi mais elevada nos períodos 3 e 5 .

Os bovinos pastejam de forma seletiva, colhendo a pastagem sempre em camadas horizontais no perfil (Hodgson, 1994 ). Observa-se no Quadro 8 que a densidade média do resíduo pós-pastejo $(57,54 \mathrm{~kg}$ MS/ha.cm) foi inferior à da planta toda $(74,07 \mathrm{~kg}$ MS/ha.cm), sugerindo um menor potencial de colheita através do pastejo à medida em que os extratos superiores da pastagem são consumidos.

Quadro 8. Variáveis relacionadas com a produção e o fracionamento da planta toda e do resíduo pós-pastejo.

\begin{tabular}{lcccc}
\hline Componentes & Planta toda & Resíduo & Média & CV \% \\
\hline Altura (cm) & $168,40^{\mathrm{a}}$ & $96,52^{\mathrm{b}}$ & 132,46 & 22,20 \\
Densidade & $74,07^{\mathrm{a}}$ & $57,54^{\mathrm{b}}$ & 65,80 & 28,92 \\
(kg MS/ha.cm) & & & & \\
Haste/folha & $1,09^{\mathrm{b}}$ & $3,88^{\mathrm{a}}$ & 2,48 & 48,99 \\
Folhas na MS (\%) & $40,58^{\mathrm{a}}$ & $16,32^{\mathrm{b}}$ & 28,45 & 39,66 \\
Hastes na MS (\%) & $44,26^{\mathrm{b}}$ & $63,30^{\mathrm{a}}$ & 53,78 & 18,23 \\
Senescente na MS (\%) & $15,16^{\mathrm{a}}$ & $20,38^{\mathrm{a}}$ & 17,77 & 47,88 \\
\hline
\end{tabular}

Letras diferentes na linha indicam diferença significativa entre média, de acordo com o teste de Tukey a $5 \%$.

Dessa forma os resultados observados nesse experimento sugerem que pastejos mais intensos e/ou mais freqüentes, poderiam ter sido efetuados para a obtenção de um 
maior aproveitamento da forragem. O manejo do capim Tobiatã baseado na altura ou quantidade de MS do resíduo pós-pastejo, possivelmente proporciona uma maior eficiência de colheita, assim como uma melhor qualidade do material consumido.

Caso a altura de resíduo de $40 \mathrm{~cm}$ proposta como diretriz inicial de manejo fosse obtida e, considerando-se uma densidade do resíduo média de $57,54 \mathrm{~kg}$ de $\mathrm{MS} / \mathrm{ha} . \mathrm{cm}$ (Quadro 8), obter-se-ia um resíduo aproximado de $2.300 \mathrm{~kg} \mathrm{MS} / \mathrm{ha}$. Esse valor é superior ao observado no resíduo pós-pastejo do período 1 ( $1.491 \mathrm{~kg} \mathrm{MS} / \mathrm{ha})$, o qual já foi suficiente para proporcionar um vigor de rebrota de $368 \mathrm{~kg} \mathrm{MS} / \mathrm{ha}$.dia. Esses dados sugerem que residuos inferiores aos observados nesse experimento não comprometeriam a intensidade de rebrota do capim Tobiatã, ao menos nos padrões de manejo e fertilidade utilizadas.

\subsection{Qualidade Nutritiva}

A composição bromatológica das folhas do capim Tobiatã, coletadas durante o período experimental, encontra-se no Quadro 9. Os valores de PB das folhas da planta toda nos períodos de observação foram respectivamente de 14,$31 ; 12,73 ; 12,16 ; 12,59$ e $13,49 \%$. Não houve diferença significativa entre os períodos. Sarmento et al. (1997) estudando o capim Tobiatã pastejado em ciclo de 24 dias, obtiveram teores de PB variando de 8 a $13 \%$ nas folhas e de 6 a $9 \%$ nas hastes dessa planta. Por sua vez, o teor de PB das hastes na planta toda também não apresentou variação significativa, sendo que a média do experimento para essa fração foi de $10,98 \%$ (Quadro 10). 
Ainda no Quadro 9, observa-se que o FDN das folhas na planta toda não apresentou diferença entre os cinco períodos analisados. Para um período de crescimento de 33 dias, a equação de Barbosa \& Euclides (1997) sugerida para $P$. maximum, estima um teor de $74,4 \%$ para as folhas, enquanto o valor médio de FDN observado no capim Tobiatã foi de $65,75 \%$ nessa fração.

O teor de FDA dos períodos 3 e 4 não diferiu. O valor de $45,63 \%$ no período 4 foi superior aos dos períodos $1(42,36 \%), 2(43,45 \%)$ e $5(43,53 \%)$, sendo esses semelhantes entre si. O teor médio de FDA foi de $43,87 \%$ na MS das folhas da planta toda.

Quadro 9. Análise bromatológica e DIVVMS de folhas na planta toda.

\begin{tabular}{lccccccc}
\hline Componente & \multicolumn{5}{c}{ Periodo } & Média & CV \\
\cline { 2 - 6 } & \multicolumn{1}{c}{1} & 2 & 3 & 4 & 5 & \\
MS & $17,39^{\mathrm{bc}}$ & $18,24^{\mathrm{bc}}$ & $20,35^{\mathrm{ab}}$ & $21,04^{\mathrm{a}}$ & $20,72^{\mathrm{a}}$ & 19,55 & 6,43 \\
PB & $14,31^{\mathrm{a}}$ & $12,73^{\mathrm{a}}$ & $12,16^{\mathrm{a}}$ & $12,59^{\mathrm{a}}$ & $13,49^{\mathrm{a}}$ & 13,05 & 8,14 \\
FDN & $63,42^{\mathrm{a}}$ & $67,07^{\mathrm{a}}$ & $66,32^{\mathrm{a}}$ & $67,73^{\mathrm{a}}$ & $64,20^{\mathrm{a}}$ & 65,75 & 1,93 \\
FDA & $42,36^{\mathrm{b}}$ & $43,45^{\mathrm{b}}$ & $44,39^{\mathrm{ab}}$ & $45,63^{\mathrm{a}}$ & $43,53^{\mathrm{b}}$ & 43,87 & 1,73 \\
LIG & $2,97^{\mathrm{b}}$ & $3,06^{\mathrm{b}}$ & $3,39^{\mathrm{ab}}$ & $3,93^{\mathrm{a}}$ & $3,86^{\mathrm{a}}$ & 3,33 & 6,29 \\
DIVVMS & $75,50^{\mathrm{a}}$ & $73,92^{\mathrm{ab}}$ & $74,89^{\mathrm{ab}}$ & $73,49^{\mathrm{b}}$ & $73,48^{\mathrm{b}}$ & 74,25 & 4,38 \\
\hline
\end{tabular}

Letras diferentes da linha indicam diferença significativa entre médias, de acordo com o teste de Tukey a $5 \%$.

O teor de lignina das folhas também apresentou um aumento com o avançar dos períodos, variando de $2,97 \%$ (periodo 1) a 3,93\% (periodo 4), demonstrando assim, uma queda na qualidade nutritiva do material. 
A digestibilidade in vitro verdadeira da MS (DIVVMS) das lâminas foliares na planta toda diferiu apenas do primeiro para os dois últimos períodos, apresentando os valores de 75,$50 ; 73,92 ; 74,89 ; 73,49$ e $73,48 \%$ para os respectivos períodos de observação. A média dos períodos foi de $74,25 \%$ de DIVVMS. Para que se possa estimar o valor da digestibilidade aparente os valores de DIVVMS devem ser subtraídos de $12,9 \%$ (Van Soest, 1982), portanto a média de digestibilidade in vitro da matéria seca (DIVMS) para as folhas do capim Tobiatã nesse experimento foi de $64,27 \%$ e os valores para os respectivos períodos analisados de: 65,$76 ; 64,38 ; 65,23 ; 64,01$ e $64,00 \%$.

Quadro 10. Análise bromatológica de folhas no resíduo pós-pastejo.

\begin{tabular}{|c|c|c|c|c|c|c|c|}
\hline \multirow[t]{3}{*}{ Componente } & \multicolumn{5}{|c|}{ Período } & \multirow[t]{3}{*}{ Média } & \multirow[t]{3}{*}{$\mathrm{CV}$} \\
\hline & 1 & 2 & 3 & 4 & 5 & & \\
\hline & \multicolumn{5}{|c|}{$\%$} & & \\
\hline MS & $14,70^{\mathrm{c}}$ & $15,88^{b c}$ & $16,27^{b}$ & $19,70^{\mathrm{a}}$ & $18,39^{\mathrm{a}}$ & 16,99 & 4,05 \\
\hline PB & $12,76^{\mathrm{a}}$ & $10,70^{\mathrm{a}}$ & $9,87^{\mathrm{a}}$ & $10,84^{\mathrm{a}}$ & $10,76^{\mathrm{a}}$ & 10,98 & 9,76 \\
\hline FDN & $64,90^{\mathrm{c}}$ & $68,66^{\mathrm{a}}$ & $65,18^{b c}$ & $67,78^{a b}$ & $66,87^{\mathrm{abc}}$ & 66,68 & 1,59 \\
\hline FDA & $43,41^{\mathrm{a}}$ & $45,34^{a}$ & $43,23^{a}$ & $44,21^{\mathrm{a}}$ & $42,74^{a}$ & 43,78 & 2,67 \\
\hline LIG & $4,09^{a}$ & $3,46^{b}$ & $3,33^{b}$ & $3,54^{\mathrm{ab}}$ & $3,87^{\mathrm{ab}}$ & 3,66 & 6,06 \\
\hline
\end{tabular}

Letras diferentes da linha indicam diferença significativa entre médias, de acordo com o teste de Tukey a $5 \%$.

No Quadro 10 observa-se que nas folhas do resíduo pós-pastejo o teor de FDN apresentou valores de $64,90 \%$ (período 1) a $68,66 \%$ (período 2), com média geral de $66,68 \%$ durante todo experimento. As hastes sofreram um aumento gradativo do teor de FDN (Quadros 11 e 12). A haste foi o principal constituinte do resíduo, de tal forma que essa fração da planta foi amadurecendo com o decorrer dos períodos. Andrade (1987) 
observou em capim Tobiatã um significativo efeito da maturidade no teor de FDN da forrageira, sendo que dos 28 aos 56 dias de crescimento o teor aumentou de 68,45 para $77,85 \%$.

Ford et al. (1979) observaram em estudo com 24 espécies de gramíneas tropicais um aumento do teor de FDN à medida em que a temperatura durante o crescimento foi aumentando. As hastes de gramíneas tropicais são mais sensíveis à perda de qualidade nutricional do que as folhas, podendo perder de 0,5 a $1,0 \%$ de digestibilidade por unidade de temperatura $\left({ }^{\circ} \mathrm{C}\right)$ adicional a que são submetidas durante $\mathrm{o}$ período de crescimento (Wilson, 1994).

Quadro 11. Análise bromatológica de hastes na planta toda.

\begin{tabular}{|c|c|c|c|c|c|c|c|}
\hline \multirow[t]{2}{*}{ Componentes } & \multicolumn{5}{|c|}{ Período } & \multirow[t]{2}{*}{ Média } & \multirow[t]{2}{*}{$\mathrm{CV}$} \\
\hline & 1 & 2 & 3 & 4 & 5 & & \\
\hline & \multicolumn{7}{|c|}{$\%$} \\
\hline MS & $9,50^{\mathrm{c}}$ & $11,12^{b c}$ & $14,60^{a}$ & $13,54^{\mathrm{ab}}$ & $15,03^{\mathrm{a}}$ & 12,76 & 11,19 \\
\hline PB & $7,94^{\mathrm{a}}$ & $7,06^{\mathrm{a}}$ & $5,15^{b}$ & $5,14^{b}$ & $4,87^{b}$ & 6,03 & 9,03 \\
\hline FDN & $63,80^{d}$ & $66,79^{c}$ & $72,41^{b}$ & $73,03^{b}$ & $75,52^{a}$ & 70,31 & 0,86 \\
\hline FDA & $47,03^{c}$ & $50,94^{b}$ & $53,72^{a}$ & $53,83^{a}$ & $54,63^{a}$ & 52,03 & 1,23 \\
\hline LIG & $3,46^{\mathrm{c}}$ & $4,39^{b}$ & $6,28^{a}$ & $6,15^{a}$ & $6,17^{a}$ & 5,29 & 4,97 \\
\hline
\end{tabular}

Letras diferentes da linha indicam diferença significativa entre médias, de acordo com o teste de Tukey a 5\%.

Com o avançar dos períodos o teor de lignina foi significativamente elevado na fração haste (planta toda e resíduo), com maior intensidade do que nas folhas. Nos Quadros 11 e 12 observamos que os valores de lignina aumentaram significativamente de 
3,46 para $6,17 \%$ e 3,22 para $6,68 \%$ do período 1 para o 5 , nas hastes da planta toda e do resíduo pós-pastejo, respectivamente.

Quadro 12. Análise bromatológica de hastes no resíduo pós-pastejo.

\begin{tabular}{|c|c|c|c|c|c|c|c|}
\hline \multirow[t]{2}{*}{ Componentes } & \multicolumn{5}{|c|}{ Período } & \multirow[t]{2}{*}{ Média } & \multirow[t]{2}{*}{$\mathrm{CV}$} \\
\hline & 1 & 2 & 3 & 4 & 5 & & \\
\hline & \multicolumn{7}{|c|}{$\%$} \\
\hline MS & $9,26^{\mathrm{c}}$ & $18,52^{\mathrm{a}}$ & $13,27^{b}$ & $15,96^{\mathrm{ab}}$ & $15,35^{a b}$ & 14,47 & 12,03 \\
\hline PB & $8,88^{a}$ & $7,24^{\mathrm{ab}}$ & $5,74^{b}$ & $5,88^{b}$ & $5,55^{b}$ & 6,67 & 9,71 \\
\hline FDN & $62,79^{c}$ & $67,07^{\mathrm{b}}$ & $70,44^{\mathrm{a}}$ & $69,53^{a b}$ & $68,91^{a b}$ & 67,75 & 1.38 \\
\hline FDA & $46,45^{c}$ & $43,45^{d}$ & $52,55^{b}$ & $55,27^{a b}$ & $55,51^{a}$ & 50,65 & 2,12 \\
\hline LIG & $3,22^{b}$ & $3,06^{b}$ & $5,44^{\mathrm{a}}$ & $6,41^{a}$ & $6,68^{a}$ & 4,96 & 9,26 \\
\hline
\end{tabular}

Letras diferentes da linha indicam diferença significativa entre médias, de acordo com o teste de Tukey a $5 \%$.

$\mathrm{O}$ aumento claro no teor de lignina das hastes com o avançar dos pastejos pode ser explicado pelo envelhecimento das mesmas, que por não serem consumidas tornavamse mais rígidas após cada ciclo de pastejo. A maturidade é a maior responsável pelo aumento dos teores de lignina nas forrageiras (Albrecht et al., 1987 e Jung \& Vogel, 1986).

Comparando-se as diversas frações da planta, observa-se que os teores de PB foram notadamente diferentes, sendo no geral maiores para as folhas do que nas hastes (Quadro 13). No pastejo simulado, nas folhas da planta toda, nas folhas do resíduo, nas hastes da planta toda, e nas hastes do resíduo os teores médios de PB foram de 14,46; 13,$05 ; 10,98 ; 6,03 ;$ e $6,67 \%$ de PB na MS, respectivamente. 
Quadro 13. Análise bromatológica das frações da planta (pastejo simulado, folhas e hastes da planta toda; folhas e hastes do resíduo pós-pastejo).

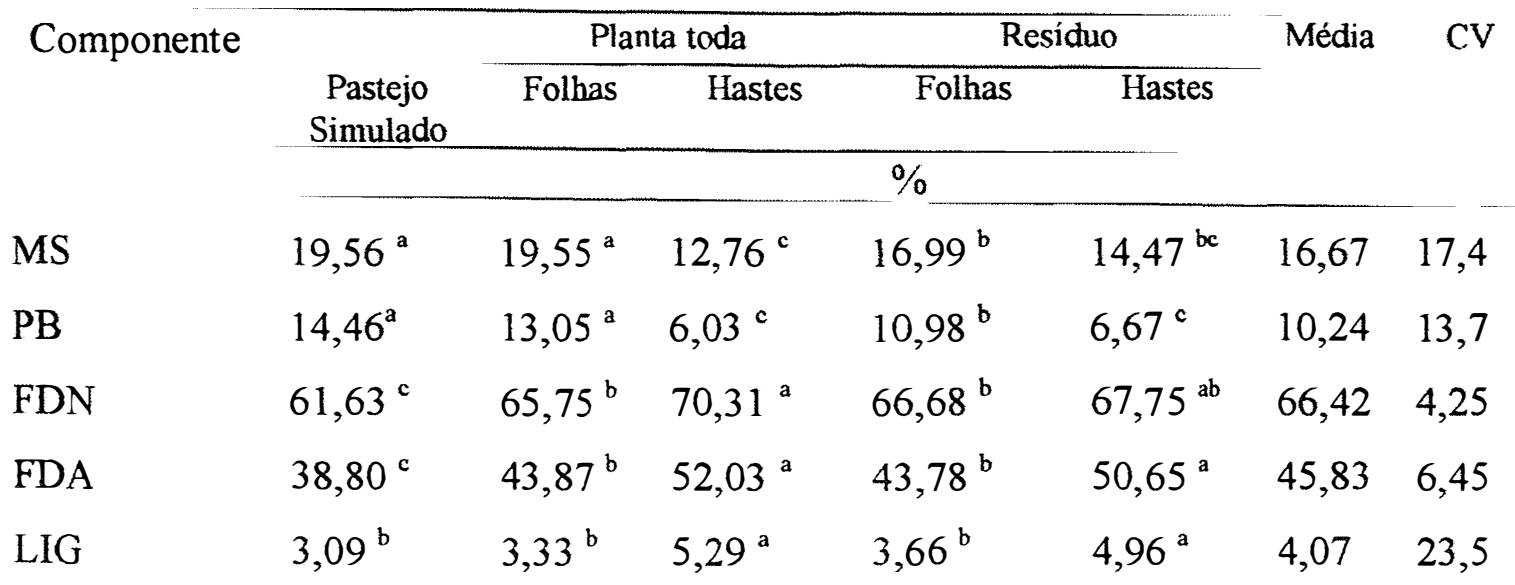

Letras diferentes da linha indicam diferença significativa entre médias, de acordo com o teste de Tukey a $5 \%$.

Nota-se que embora o teor de PB das folhas da planta toda (13,05\%) tenha sido maior que nas folhas do resíduo (10,98\%), este último ainda está acima dos $7 \%$ sugeridos por Wilson \& Minson (1980) como nivel mínimo para manutenção da atividade ruminal. Níveis acima de 7\% de PB nas hastes do capim Tobiatã só foram observados nos períodos iniciais do ciclo de pastejo (Quadros 11 e 12).

No Quadro 13 observa-se que os teores de FDN foram menores no pastejo simulado $(61,63 \%)$, do que nas folhas da planta toda $(65,75 \%)$ e do resíduo $(66,68 \%)$, hastes da planta toda $(70,31 \%)$ e do resíduo $(67,75 \%)$. Tecidos vegetais com elevado teor de parede celular (FDN) em geral apresentam baixo consumo (Akin, 1989). O conteúdo celular apresenta digestibilidade praticamente total, enquanto que na parede celular a digestibilidade pode variar entre 30 a $60 \%$, podendo limitar o consumo devido a uma redução na taxa de passagem ruminal (Poppi et al., 1985 citado por Wilson, 1994). 
Os conteúdos de FDA nas diversas frações da planta também diferiram. Em ordem crescente foram respectivamente 38,$80 ; 43,78 ; 43,87 ; 50,65$ e $52,03 \%$ para a fração pastejo simulado, folhas do resíduo, folhas da planta toda, hastes do resíduo e hastes da planta toda (Quadro 13). Houve uma tendência de aumento no valor de FDA do primeiro para os demais períodos praticamente em todas as frações da planta, com exceção das folhas do resíduo pós-pastejo. O teor de FDA está altamente correlacionado com a digestibilidade da forragem (Van Soest, 1994). Dessa forma, observa-se que embora o período de descanso da pastagem tenha sido fixado em 33 dias, houve uma queda de qualidade nutricional da forragem disponível do primeiro para os demais períodos.

Os teores de lignina observados no Quadro 13 foram notadamente maiores nas hastes do que nas folhas. A lignina é o componente de maior significância na indisponibilização da parede celular à digestão por herbívoros e sistemas anaeróbicos de digestão (Van Soest, 1994). Não só o teor de lignina está associado à menores digestibilidades da fibra, como também a sua composição química. $\mathrm{O}$ teor e proporção de seus constituintes, também variam em função da maturidade e do tecido lignificado, alterando a intensidade de seu efeito de indisponibilização de carboidratos estruturais (Jung,1989).

As hastes do capim Tobiatã neste experimento apresentaram valores significativamente maiores no teor de lignina pois as hastes de gramíneas tropicais em geral possuem grande proporção de tecidos lignificados de baixa digestão como epiderme, esclerênquima e xilema (Albrecht et al., 1987). Os teores de lignina observados 
para as diversas frações da planta foram 3,$09 ; 3,33 ; 3,66 ; 5,29$ e 4,96\% no pastejo simulado, nas folhas da planta toda, nas folhas do resíduo, nas hastes da planta toda e nas hastes do resíduo, respectivamente (Quadrol3).

As amostras de pastejo simulado demonstraram uma tendência de redução na sua qualidade nutricional, com o avançar da estação de pastejo. No Quadro 14 observase que o teor de PB no primeiro período tendeu a ser o mais elevado (16,75\%) enquanto que no período 4 houve uma redução para $12,60 \%$. Os períodos 2,3 e 5 não apresentaram diferença significativa para com os demais. Sabendo-se que a principal fração colhida no pastejo simulado foram lâminas foliares, poder-se-ia esperar que as mesmas tivessem uma queda semelhante no teor de $\mathrm{PB}$, como no período 4 , porém tal fato não foi observado (Quadro 9). Em folhas jovens a concentração de N é mais elevada (Corsi \& Nascimento, 1994), assim como nas regiões de tecido meristemático (Skinner \& Nelson, 1995). Assim, possivelmente a amostragem, simulando o comportamento de pastejo seletivo da forragem pelos animais, concentrou-se mais em folhas em expansão e recentemente expandidas, explicando a tendência a um maior valor de $\mathrm{PB}$ no pastejo simulado $(14,46 \%)$ do que nas folhas $(13,05 \%)$, como observado no Quadro 13.

Os teores de PB observados neste experimento, para o capim Tobiatã, são considerados elevados quando comparados à outros dados de literatura. Balsalobre (1996) descreveu teores de PB médios de 7,80 e 8,73\% no pastejo simulado e nas folhas do capim elefante manejado em sistema rotacionado, respectivamente. No entanto, Barbosa \& Euclides (1997) observaram médias de 11,$6 ; 11,1 ;$ e $12,3 \%$ de PB para as folhas dos cultivares de Panicum maximum: Mombaça, T21 e Tanzânia respectivamente, 
submetidos à um ciclo de pastejo de 42 dias. Fazendo-se uso de regressão sugerida por esses autores $(R=0,88)$ estimar-se-ia um teor de $11,95 \%$ de $\mathrm{PB}$ nas folhas para um período de crescimento de 33 dias, enquanto o valor observado foi de $13,05 \%$.

Quadro 14. Análise bromatológica e DIVVMS de amostras de pastejo simulado.

\begin{tabular}{|c|c|c|c|c|c|c|c|}
\hline \multirow[t]{2}{*}{ Componentes } & \multicolumn{5}{|c|}{ Período } & \multirow[t]{2}{*}{ Média } & \multirow[t]{2}{*}{$\mathrm{CV}$} \\
\hline & 1 & 2 & 3 & 4 & 5 & & \\
\hline & & & & $\%$ & & & \\
\hline MS & $18,34^{\mathrm{a}}$ & $19,98^{\mathrm{a}}$ & $19,89^{\mathrm{a}}$ & $20,52^{a}$ & $20,49^{a}$ & 19,56 & 5,23 \\
\hline PB & $16,75^{\mathrm{a}}$ & $14,65^{a b}$ & $14,37^{\mathrm{ab}}$ & $12,60^{b}$ & $13,96^{\mathrm{ab}}$ & 14,46 & 8,02 \\
\hline FDN & $60,05^{\mathrm{a}}$ & $60,77^{a}$ & $61,74^{\mathrm{a}}$ & $62,95^{a}$ & $62,64^{a}$ & 61,63 & 1,99 \\
\hline FDA & $35,73^{b}$ & $40,80^{a}$ & $37,52^{a b}$ & $39,90^{a}$ & $40,06^{\mathrm{a}}$ & 38,80 & 3,75 \\
\hline LIG & $3,15^{a}$ & $3,18^{a}$ & $3,45^{\mathrm{a}}$ & $2,99^{a}$ & $2,67^{\mathrm{a}}$ & 3,09 & 11,6 \\
\hline DIVVMS & $82,98^{\mathrm{a}}$ & $79,88^{a b}$ & $79,74^{\mathrm{ab}}$ & $78,34^{b}$ & $79,52^{b}$ & 80,09 & 1,53 \\
\hline
\end{tabular}

Letras diferentes da linha indicam diferença significativa entre médias, de acordo com o teste de Tukey a 5\%.

A DIVVMS do material colhido como pastejo simulado foi menor nos períodos 4 e 5 do que no período 1 (Quadro 14). Convertendo-se esses valores para digestibilidade aparente, da mesma forma como feito para as folhas na discussão do Quadro 9, obtêm-se nos respectivos períodos de observação, os valores de 72,$28 ; 69,58 ; 69,45 ; 68,23$ e $69,26 \%$ de DIVMS, com média do experimento de $69,76 \%$ na fração pastejo simulado. Costa \& Oliveira (1997) observaram em capim Tobiatã valores de 64,$3 ; 62,7$ e $58,2 \%$ de DIVMS quando a forragem foi cortada a $30 \mathrm{~cm}$ do solo nas idades de 28,42 e 56 dias de crescimento. Os valores de digestibilidade observados para as folhas e para o pastejo simulado do capim Tobiatã permitem inferir que, o desempenho animal sob pastejo 
possivelmente é mais sensível à mudanças em aspectos que alterem o consumo de MS, do que sua qualidade. Assim, o enfoque no sentido de aumentar a densidade da forragem e a sua proporção de folhas, parece bastante pertinente no que concerne ao manejo de gramíneas tropicais de hábito cespitoso.

\subsection{Filocrono e taxa de aparecimento de folhas}

No Quadro 15, pode-se observar que os valores de filocrono, expressos em $\mathrm{GD} /$ folha, foram menores durante os meses inicial e final da estação de pastejo. Tanto em dezembro $(115,97 \mathrm{GD} /$ folha $)$ quanto em abril (118,50 $\mathrm{GD} /$ folha $)$, os valores apresentaram-se significativamente menores que durante o período de janeiro a março $(178,24 ; 163,30$ e $163,62 \mathrm{GD} /$ folha, respectivamente), quando mantiveram-se estáveis. Dados de filocrono em gramineas tropicais utilizando unidades térmicas como referência são raros na literatura (Nabinger, 1997). Em capim elefante anão, Almeida et al. (1997), observaram que as folhas apareciam em média a cada 85 GD, ou seja, em menor acúmulo de graus-dia que no capim Tobiatã no presente trabalho. A medida de filocrono é mais vasta em literatura de gramíneas temperadas. Davies (1988), por exemplo, relatou que o azevém perene apresenta um filocrono médio de 110 GD, enquanto a Festuca de 230 GD/folha. 
Quadro 15. Medidas de filocrono e taxa de aparecimento de folhas.

\begin{tabular}{|c|c|c|c|}
\hline \multirow[t]{2}{*}{ Período } & \multicolumn{2}{|c|}{ Filocrono } & Taxa de aparecimento de \\
\hline & $\mathrm{GD}\left({ }^{\circ} \mathrm{C}\right) /$ folha & dias/folha & (folhas/dia) \\
\hline Dezembro & $115,97^{b}$ & $8,46^{c}$ & $0,12^{c}$ \\
\hline Janeiro & $178,24^{\mathrm{a}}$ & $12,94^{\mathrm{a}}$ & $0,08^{\mathrm{a}}$ \\
\hline Fevereiro & $163,30^{\mathrm{a}}$ & $10,44^{b}$ & $0,10^{b}$ \\
\hline Março & $163,62^{\mathrm{a}}$ & $11,35^{a b}$ & $0,09^{\mathrm{ab}}$ \\
\hline Abril & $118,50^{b}$ & $7,89^{\mathrm{c}}$ & $0,13^{\mathrm{c}}$ \\
\hline Média & 147,93 & 10,22 & 0,10 \\
\hline CV \% & 22,58 & 22,94 & 22,94 \\
\hline
\end{tabular}

Letras diferentes na coluna indicam diferença significativa entre médias, de acordo com o teste de Tukey a $5 \%$.

O valor do filocrono expresso em GD, depende da temperatura basal considerada, ou seja, aquela onde o crescimento ou o acúmulo de matéria seca é considerado desprezivel para uma determinada espécie. Enquanto para as gramíneas temperadas a temperatura basal considerada é geralmente de $0^{\circ} \mathrm{C}$, para as tropicais essa mesma temperatura é de $10^{\circ} \mathrm{C}$ (Nabinger, 1997). Outras fontes de variação na medida do filocrono são ressaltadas por Wilhelm \& McMaster (1995). Esses autores lembram que alguns fatores podem ser responsáveis por reduzir a precisão da medida do filocrono. Todas medidas efetuadas levam em conta a temperatura do ar, porém essa temperatura nem sempre está diretamente relacionada com a temperatura na região do meristema apical da planta, em função das diferentes coberturas de solo e alturas do meristema. Como a temperatura do ar oscila durante todo o dia, assumir que a temperatura média a que a planta foi submetida seja a média entre a máxima a mínima diária, pode significar uma aproximação grosseira. Mesmo assim, no campo, essa metodologia se mostra favorável, devido às correlações elevadas entre a temperatura do ar e o filocrono em GD. 
O acúmulo de unidades térmicas é uma estimativa simplificada da energia disponível à fotossíntese, podendo ser considerada uma medida de tempo mais representativa do que as de caráter cronológico (Ometto, 1981). No entanto, neste experimento os valores de filocrono em dias e GD apresentaram um comportamento bastante semelhante, tendendo a reduzir-se nos períodos inicial e final da estação de crescimento.

O filocrono (dias/folha) médio observado para o capim Tobiatã no período experimental foi de 10,22 dias/folha (Quadro 15). Os valores de dezembro a abril foram respectivamente: 8,$46 ; 12,94 ; 10,44 ; 11,35$ e 7,89 dias/folha. O mês de dezembro apresentou um filocrono (dias/folha) igual à abril porém inferior aos demais, assim como janeiro e março diferiram de abril. Os demais meses não apresentaram diferença significativa entre si.

A taxa de aparecimento de folhas (folhas/dia) foi calculada como o inverso do filocrono (dias/folha) e é apresentada no Quadro 15. Os valores observados para os cinco períodos de avaliação foram de 0,$12 ; 0,08 ; 0,10 ; 0,09$ e 0,13 folhas/dia, respectivamente. A taxa de aparecimento de folhas é influenciada principalmente pela estação do ano (Parsons \& Penning, 1988) e pela temperatura (Collins \& Jones, 1988). Barbosa et al. (1997) encontraram uma grande variação das taxas de aparecimento de folha para capim Tobiatã cortado a $40 \mathrm{~cm}$, em função da época do ano. Esses autores estimaram através de regressão linear, para um período de crescimento de 35 dias, as seguintes taxas de aparecimento de folhas: 0,$10 ; 0,12 ; 0,11$ e 0,08 folhas/dia para as estações inverno, primavera, verão e outono, respectivamente. 
Os valores obtidos no presente experimento diferenciam o cultivar Tobiatã de outros cultivares de $P$. maximum quanto a taxa de aparecimento de folhas. A taxa de aparecimento média para o capim Tobiatã foi de 0,09 folhas/dia durante o período experimental. Gomide \& Gomide (1996) observaram valores de 0,15 e 0,19 folhas/dia nos cultivares Mombaça e Tanzânia durante o período de estabelecimento.

A medida do filocrono em GD/folha tendeu a mostrar-se mais estável do que quando expressa em dias/folha. Observa-se no Quadro 15 que durante os meses de janeiro e fevereiro, por exemplo, os valores de filocrono foram diferentes em dias/folha, no entanto, o maior acúmulo de unidades térmicas durante o mês de fevereiro fez com que as medidas fossem iguais em GD/folha. Assim, aparentemente as medidas de filocrono expressas em GD foram mais estáveis no que se refere às folhas de capim Tobiatã.

\subsection{Taxa de alongamento de folhas}

No Quadro 16 observa-se que as taxas de alongamento de folhas do capim Tobiatã variaram de acordo com o mês de observação, apresentando média de 4,05 $\mathrm{cm} /$ folha.dia durante o experimento. Fatores externos, tais como temperatura (Robson, 1981) e estação do ano (Barbosa et al., 1996), podem influenciar a taxa de alongamento de folhas. As taxas de alongamento dos meses de novembro a abril apresentaram os valores de 4,$38 ; 4,37 ; 4,28 ; 4,07 ; 3,69$ e 3,42 cm/folha.dia, respectivamente (Quadro 16). As taxas de alongamento de folhas de novembro e dezembro diferiram apenas dos meses 
de março e abril. Os valores de novembro a fevereiro diferiram também de abril. Os demais valores não apresentaram diferença significativa entre si.

Quadro 16. Taxa de alongamento de folhas e de folhas/perfilho.

$\begin{array}{lrc}\text { Mês } & \mathrm{cm} / \text { folha.dia } & \mathrm{cm} / \text { perfilho.dia } \\ \text { Novembro } & 4,38^{\mathrm{a}} & 5,35^{\mathrm{b}} \\ \text { Dezembro } & 4,37^{\mathrm{a}} & 7,01^{\mathrm{a}} \\ \text { Janeiro } & 4,28^{\mathrm{ab}} & 7,52^{\mathrm{a}} \\ \text { Fevereiro } & 4,07^{\mathrm{ab}} & 6,98^{\mathrm{a}} \\ \text { Março } & 3,69^{\mathrm{bc}} & 7,40^{\mathrm{a}} \\ \text { Abril } & 3,42^{\mathrm{c}} & 6,98^{\mathrm{a}} \\ \text { Média } & 4,05 & 6,87 \\ \text { CV\% } & 14,51 & 15,81\end{array}$

Letras diferentes nas colunas indicam diferença significativa entre médias, de acordo com o teste de Tukey a $5 \%$.

As diferenças observadas na taxa de alongamento de folhas podem ser em grande parte atribuídas às temperaturas médias diárias observadas nos meses de novembro a abril. A taxa média de alongamento de folhas para a estação completa de pastejo $(4,05 \mathrm{~cm} /$ folha dia) sugere o elevado potencial de produção de biomassa vegetal do capim Tobiatã quando comparado com outras gramíneas. Corsi et al. (1994) em trabalho com gramíneas do gênero Brachiaria, encontraram diferentes taxas de alongamento em função da estação do ano. Foram observados para a primavera e verão os respectivos valores: 1,23 e $1,19 \mathrm{~cm} /$ folha.dia (B. brizantha), 0,38 e $0,51 \mathrm{~cm} /$ folha.dia (B. humidicola) e 0,83 e $0,91 \mathrm{~cm} /$ folha dia (B.decumbens). Barbosa et al. (1996) em experimento com $P$. maximum, estimaram as seguintes taxas de alongamento foliar para o capim Tobiatã: 5,$23 ; 7,57$ e $3,21 \mathrm{~cm} /$ folha dia para as estações de primavera, verão e outono, respectivamente. Pinto et al. (1994b) observaram valores médios de 6,0 e 5,2 
cm/folhadia para capim Guiné ( $P$. maximum cv. Guinea) e capim Setária (Setharia anceps cv. Kazungula), respectivamente.

A taxa de alongamento de folhas é também sensivel ao déficit hídrico, pois o aumento em volume das células vegetais é função da pressão de turgor (Horst et al., 1978). Nos meses em que a taxa de alongamento foi menor, a precipitação pluvial também apresentou os menores níveis, sendo de 171,8 e $71 \mathrm{~mm} /$ dia nos meses de março e abril comparada a 358 e $215,5 \mathrm{~mm}$ /dia para janeiro e fevereiro, respectivamente (Quadro 2). Dessa forma teve-se a redução de dois fatores primordiais no alongamento das folhas de gramíneas tropicais, à medida em que a estação de pastejo avança. Possivelmente, tanto a intensidade do metabolismo foi reduzida devido à queda da temperatura (Lemaire, 1997), como também as taxas de alongamento celular, devido à menor disponibilidade hídrica (Van Loo, 1992). Dessa forma a combinação de fatores climáticos leva a menores acúmulos de matéria seca à medida em que a estação de pastejo afasta-se do solstício de verão.

A taxa de alongamento de folhas/perfilho reflete o efeito do número de folhas em expansão por perfilho, aliado ao alongamento individual de cada folha. A média de $6,87 \mathrm{~cm} /$ dia.perfilho foi observada no capim Tobiatã durante o período experimental (Quadro 16). Comparando-se os meses, apenas o valor de novembro $(5,35$ cm/perfilho.dia) diferiu dos demais. Carvalho \& Damasceno (1996) observaram um valor médio de $24 \mathrm{~cm} /$ perfilho dia em capim elefante roxo aos 28 dias de rebrota. Pinto et al. (1994b) ressaltam as grandes variações na taxa de alongamento foliar/perfilho encontradas entre genótipos de gramíneas tropicais, mesmo dentro de uma mesma 
espécie. Gomide et al. (1997) observaram em Brachiaria decumbens taxas de alongamento que variaram de 1,72 a $2,6 \mathrm{~cm} /$ perfilho dia à medida em que a biomassa do relvado aumentou de 4,4 para $11,7 \mathrm{t} \mathrm{MS/ha,} \mathrm{respectivamente.}$

\subsection{Dinâmica de fluxo de tecidos}

Os número máximos, médios e mínimos de folhas vivas expandidas/perfilho durante cada ciclo de pastejo podem ser observados no Quadro 17. O número máximo de folhas expandidas no capim Tobiatã aumentou com o avanço dos períodos de pastejo. Para os meses de observação os valores máximos de folhas expandidas/perfilho foram respectivamente 2,$33 ; 2,85 ; 4,19 ; 4,25$ e 4,85 . Aparentemente o período de descanso de 33 dias não permitiu que o capim Tobiatã expandisse todas as folhas possiveis nos meses de dezembro (2,33 folhas/perfilho) e janeiro (2,85 folhas/perfilho). Os meses de fevereiro, março e abril não diferiram significativamente entre si. Poder-se-ia inferir portanto que, a pastagem foi colhida antes de expressar seu potencial máximo de acúmulo líquido de forragem nos dois primeiros meses de observação. No entanto, se o período de descanso fosse ainda maior a dificuldade de redução da altura do resíduo póspastejo seria potencializada.

A literatura fornece alguns valores de número de folhas expandidas/perfilho em P. maximum tais como: 4,6; 4,0 e 6,0 folhas vivas/perfilho nos cultivares Guiné (Pinto, 1993), Mombaça e Vencedor (Gomide, 1994), respectivamente. 
Quadro 17. Número de folhas vivas expandidas/perfilho.

\begin{tabular}{lccc}
\hline Mês & Máxima & Mínima & Média \\
\hline Dezembro & $2,33^{\mathrm{b}}$ & $1,01^{\mathrm{c}}$ & $1,55^{\mathrm{d}}$ \\
Janeiro & $2,85^{\mathrm{b}}$ & $2,10^{\mathrm{b}}$ & $2,47^{\mathrm{c}}$ \\
Fevereiro & $4,19^{\mathrm{a}}$ & $2,70^{\mathrm{a}}$ & $3,59^{\mathrm{ab}}$ \\
Março & $4,25^{\mathrm{a}}$ & $2,28^{\mathrm{ab}}$ & $3,26^{\mathrm{b}}$ \\
Abril & $4,85^{\mathrm{a}}$ & $2,69^{\mathrm{a}}$ & $3,95^{\mathrm{a}}$ \\
Média & 3,70 & 2,16 & 2,96 \\
\hline CV\% & 17,42 & 15,59 & 13,45 \\
\hline \hline
\end{tabular}

Letras minúsculas diferentes nas colunas indicam diferença entre médias, de acordo com o teste de Tukey a $5 \%$.

O número de folhas vivas expandidas/perfilho é razoavelmente constante dentro do genótipo, dependendo das condições do meio e do manejo. Daí, tal índice prestar-se como um meio objetivo de definir a freqüência de corte ou pastejo das forrageiras, tendo em vista a maximização da eficiência de colheita, evitando-se assim perdas por senescência e morte (Gomide,1997).

Os valores mínimos de folhas vivas expandidas geralmente eram observados logo após o pastejo e apresentaram média de 2,16 folhas/perfilho (Quadro 17). Gradativamente o relvado crescia durante o período de descanso de forma a apresentar um valor médio dessa variável no ciclo de 34 dias. Foram observados os valores médios de 1,$55 ; 2,47 ; 3,59 ; 3,26$ e 3,95 folhas vivas expandidas nos perfilhos do capim Tobiatã, dos meses de dezembro a abril, respectivamente. 
Quadro 18. Número de folhas em expansão/perfilho.

\begin{tabular}{lccc}
\hline Mês & Máxima & Mínima & Média \\
\hline Dezembro & $1,97^{\mathrm{ab}}$ & $1,13^{\mathrm{b}}$ & $1,65^{\mathrm{b}}$ \\
Janeiro & $2,03^{\mathrm{a}}$ & $1,70^{\mathrm{a}}$ & $1,93^{\mathrm{a}}$ \\
Fevereiro & $1,96^{\mathrm{ab}}$ & $1,25^{\mathrm{b}}$ & $1,66^{\mathrm{b}}$ \\
Março & $1,89^{\mathrm{b}}$ & $1,25^{\mathrm{b}}$ & $1,64^{\mathrm{b}}$ \\
Abril & $1,76^{\mathrm{c}}$ & $1,01^{\mathrm{b}}$ & $1,42^{\mathrm{c}}$ \\
Média & 1,92 & 1,27 & 1,66 \\
CV \% & 16,53 & 21,04 & 18,77 \\
\hline
\end{tabular}

Letras minúsculas diferentes nas colunas indicam diferença entre médias, de acordo com o teste de Tukey a $5 \%$.

A média dos valores máximos de folhas em expansão foi de 1,92 folhas/perfilho (Quadro 18), sendo que essa variável tendeu a reduzir-se nos períodos finais de pastejo (março e abril). O número máximo de folhas em expansão/perfilho no mês de abril $(1,76)$ foi inferior a todos os demais. Os meses de dezembro, janeiro e fevereiro não diferiram entre si e apresentaram os valores máximos de 1,$97 ; 2,03$ e 1,96 folhas em expansão/perfilho, respectivamente (Quadro 18).

O valor médio de folhas em expansão no período de rebrota de 33 dias foi em média de 1,66 folhas/perfilho, atingindo seu maior valor em janeiro (1,93 folhas/perfilho) e reduzindo-se para 1,42 folhas em expansão/perfilho em abril. Nos meses de maiores taxas de acúmulo de MS (dezembro a março) o número médio de folhas em expansão/perfilho tendeu a ser maior $(1,65 ; 1,93 ; 1,66$ e 1,64 , respectivamente). $\grave{A}$ medida em que o capim crescia após o pastejo, observou-se um aumento gradual do número de folhas em expansão. Assim, o valor mínimo observado foi em média de 1,27 
folhas em expansão/perfilho durante o experimento. O número mínimo de folhas em expansão, geralmente refletia aquele encontrado nas primeiras observações de cada ciclo de pastejo. Os valores mínimos observados foram de 1,$13 ; 1,70 ; 1,25,1,25$ e 1,01 folhas em expansão/perfilho para os respectivos meses de observação. Apenas em janeiro essa variável foi significativamente maior.

$\mathrm{O}$ número de folhas senescentes/perfilho foi signicativamente maior $(\mathrm{P}<0,05)$ no mês de janeiro com relação aos outros meses. Os demais meses não diferiram entre si. A senescência de folhas foi medida em termos de folhas senescentes/perfilho por ciclo de pastejo. Durante os meses de dezembro e abril não houve sinal de senescência de folhas nos perfilhos observados. $\mathrm{O}$ número de folhas senescentes foi de $1,23 \mathrm{em}$ janeiro, 1,01 em fevereiro e 0,07 folhas/perfilho em março. Pode-se observar que nos períodos de maior acúmulo de MS, também ocorreram as maiores perdas por senescência. É interessante observar que em janeiro, quando o número de folhas expandidas ainda não havia se aproximado do máximo (Quadro 17), já havia ocorrência de folhas senescentes.

Hodgson (1990) comenta que o número máximo de folhas expandidas por perfilho é uma variável que apresenta grande constância dentro do genótipo, só ocorrendo senescência quando esse número de folhas é atingido. Em azevém perene por exemplo, só há senescência da folha mais velha quando a terceira folha viva do perfilho se expande.

Os dados observados no capim Tobiatã neste experimento, por serem fruto de uma situação específica de manejo, não devem ser utilizados como guias no manejo dessa gramínea sob pastejo. No entanto, é interessante exemplificar como as 
características observadas poderiam servir em aspectos práticos de manejo. Considerando-se um número médio de 4,5 folhas vivas/perfilho no capim Tobiatã (média aproximada dos meses de fevereiro, março e abril no Quadro 17) e que cerca de 2 folhas vivas são deixadas após o pastejo (Quadro17). Nessa condição os perfilhos do capim Tobiatã teriam que expandir mais 2,5 folhas para alcançarem o valor de 4,5 folhas/perfilho. Se o filocrono do capim Tobiatã considerado for de $147 \mathrm{GD} /$ folha (Quadro 15), então seriam necessários 2,5 folhas x $147 \mathrm{GD} /$ folha $=367,5 \mathrm{GD}$ para que 4,5 folhas se acumulassem no perfilho, antes que a senescência fosse iniciada. Utilizandose os valores de acúmulos médios mensais de GD observados no Quadro 2, e dividindose os 367,5 GD por esses valores, obtêm-se os seguintes períodos de descanso: 32,1 ; 29,$3 ; 28,2 ; 26,5 ; 25,6 ; 27,4 ; 31,0$ e 41,9 dias para os meses de outubro a maio, respectivamente. Em termos práticos o uso do período de descanso variável implicaria numa necessidade de excluir-se ou acrescentar-se área de pastejo à medida em que as condições de crescimento variam. Durante os meses de dezembro e janeiro o número observado de folhas vivas por perfilho foi significativamente menor que nos demais. No mês de janeiro, mesmo com média de 2,85 folhas vivas por perfilho, já houve sinal de senescência, com 1,23 folhas senescentes durante o mês. Tal observação não condiz com o padrão constante de fluxo de tecidos que era esperado, sugerindo que mais estudos sejam feitos nesse sentido. Estudos em condições controladas são necessários também para isolar e identificar outros fatores que porventura venham a influenciar as variáveis aqui analisadas. 


\section{CONCLUSÕES}

Os resultados permitem concluir que:

O capim Tobiatã, submetido às condições de manejo utilizadas neste experimento, não apresentou características morfofisiológicas e nutricionais constantes durante todos os meses ou períodos de observação. A freqüência de pastejo, fixada em termos cronológicos, permitiu uma considerável queda na qualidade nutricional e na eficiência de colheita do capim Tobiatã, principalmente no final da estação.

Houve aumento na quantidade e na altura do resíduo pós-pastejo à medida que os períodos avançaram, possivelmente devido à uma dificuldade crescente de colheita do material disponivel que, gradativamente, tinha aumentada suas frações menos nutritivas como hastes e material senescente. Dessa forma, a eficiência de colheita da forragem reduziu-se de 65 para $20 \%$ quando comparados os períodos iniciais e finais de observação. Possivelmente uma das maneiras de amenizar-se esse problema seria mantendo-se o resíduo pós-pastejo numa altura menor e mais constante durante toda estação de pastejo. Essa opção de rebaixamento do pasto, por sua vez, possivelmente seria mais efetivamente realizada durante o primeiro ciclo de pastejo, quando as hastes 
ainda sofreram pouco do efeito da ligificação e apresentam um maior potencial de consumo pelos animais em pastejo.

Outra opção de manejo, visando a redução das perdas, seria a de trabalhar-se com dias de descanso variáveis, aumentando a freqüência de pastejo quando as condições de crescimento vegetal forem mais favoráveis e reduzindo quando fatores como radiação e temperatura não permitam taxas de acúmulo de MS elevadas. Para tal fim, o uso do conceito do filocrono e do número de folhas vivas/perfilho no capim Tobiatã, como medidos neste experimento, parece mostrar-se como técnica promissora, muito embora outros trabalhos sejam necessários para validar ou adequar os valores encontrados para essas variáveis.

A qualidade nutricional do capim Tobiatã sofreu significativa redução com o passar dos periodos, como demonstraram os valores de DIVVMS e de PB observados nas folhas da planta e no material colhido como pastejo simulado. Muito embora tenha havido redução na qualidade do material, os valores de digestibilidade encontrados no presente experimento são considerados elevados, quando comparados com as médias de de gramineas tropicais na literatura.

Mais trabalhos são necessários para melhor se conhecer as adaptações fisiológicas e morfológicas das forrageiras tropicais à ação do animal em pastejo e à diferentes condições de manejo, de forma que se possa definir procedimentos que potencializem a colheita e utilização dessas gramineas. 


\section{REFERÊNCIAS BIBLIOGRÁFICAS}

AGUIAR, A. P. A. Possibilidades de intensificação do uso da pastagem através de rotação sem ou com uso mínimo de fertilizantes. In: SIMPÓSIO SOBRE MANEJO DA PASTAGEM, 14, Piracicaba, 1997. Anais. Piracicaba: FEALQ, 1997. p. $85-138$.

AKIN, D.E. Histological and physical factors affecting digestibility of forages. Agronomy Journal, v. 81, p. 17-45. 1989.

AKIN, D.E.; RIGSBY, L. L.; BROWN, R.H. Ultraestructure of cell wall degradation in Panicum species differing in digestibility. Crop Science, v.24, p. 156-163, 1984.

AKIN, D.E.; FALES, S. L. ; RIGSBY, L. L.; SNOOK, M. E. Temperature effects on leaf anatomy, phenolic acids, and tissue digestibility in Tall Fescue. Agronomy Journal, v. 79, p. 271-275, 1987.

AKIN, D. E. Histological and physical factors affecting digestibility of forages Agronomy Journal, v. 81, p. 17-45, 1989. 
ALBRECHT, K. A.; WEDIN, W. F.; BUXTON, D.R. Cell wall composition and digestibility of alfalfa steam and leaves. Crop Science, v. 27, p. 735-741, 1987.

ALLARD, G.; NELSON, C. J. Photosynthate partioning in basal zones os tall fescue leaf blades. Plant Physiology, v.95, p.663-668, 1991.

ALMEIDA, E. X.; SETILICH, E. A.; MARASCHIN, E. G. Oferta de forragem e variáveis morfogênicas em capim elefante anão 'cv.' Mott. ). Anais XXXlV Reunião Anual Soc. Bras. Zootecnia. Anais, Secção forragicultura. Juiz de Fora; p. $240-242,1997$.

ANDRADE, J. B. de. Estudo comparativo de três capins da espécie Panicum maximum, Jacq. (colonião, Tobiatã e K-187-B),

Piracicaba, 1987. 133 p. Dissertação (Mestrado) - Escola Superior de Agricultura “Luiz de Queiroz”, Universidade de São Paulo.

ANDRADE, I.; GOMIDE J. A . Curva de crescimento e valor nutritivo de capimelefante (Pennisetum purpureum, Shum.) Revista Ceres, v. 28 p. $431-446.1971$.

AOAC. Association of Official Analytical Chemists. 1990. Official Methods of Analysis. $15^{\text {a }}$ ed. AOAC, Arlington, VA.

ASSIS, A. G. de. Produção de leite a pasto no Brasil. In: SIMPÓSIO INTERNACIONAL SOBRE PRODUÇÃO ANIMAL EM PASTEJO, 1 Viçosa, 1997. Anais. Viçosa: ed. José Alberto Gomide, 1997, p. 381-410. AWAD, M.; CASTRO, P.R.C. Introdução à fisiologia vegetal. São Paulo: Nobel. 1983. $77 \mathrm{p}$. 
BAKER, C. K.; GALLAGER, J.N.; MONTEITH J.L. Daylenght and leaf appearance in winter wheat. Plant Cell Environment v.3, p.285-287, 1980.

BALSALOBRE, M. A. A. Desempenho de vacas em lactação sob pastejo rotacionado de capim-elefante (Pennisetum purpureum Schum.) Piracicaba, 1996. 139 p. Dissertação (Mestrado) - Escola Superior de agricultura "Luiz de Queiroz", Universidade de São Paulo.

BARBOSA, M. A. A. F., DAMASCENO, J. C., CECATO, U., SAKAGUTI, E. S., Dinâmica do Aparecimento, Expansão e Senescência de Folhas em diferentes cultivares de Panicum maximum Jacq. In: REUNIÃO ANUAL DA SOCIEDADE BRASILEIRA DE ZOOTECNIA, 33, Fortaleza, 1996. Anais. Fortaleza: SBZ, 1996, p. 101-103.

BARBOSA, M. A. A. F.,CECATO, U., ONORATO, M. W.,COELHO E. M. Estudo do perfilhamento do capim Mombaça (Panicum maximum Jacq.). In: REUNIÃO ANUAL DA SOCIEDADE BRASILEIRA DE ZOOTECNIA, 34, Juiz de Fora, 1997. Anais. Juiz de Fora: SBZ, 1997, p. 114-116. 1997.

BARBOSA, R. A.; EUCLIDES, V. P. B. Valores nutritivos de três ecótipos de Panicum maximum . In: REUNIÃO ANUAL DA SOCIEDADE BRASILEIRA DE ZOOTECNIA, 34, Juiz de Fora, 1997. Anais. Juiz de Fora: SBZ, 1997, p. 53-55.

BJORKMAN, O. Some viewpoints on photosyntetic response and adaptation to enviromental stress. In: BRIGGS, W. R. Ed. Photosynthesis. New York: Alan R. Liss, 1989. p. 45-58. 
BLASER, R.E.; HAMMES JR., R.C.; FONTENOT, J.P.; BRYANT, H.T.; POLAN, C.E.; WOLF, D.D.; McCLAUGHERTY, F.S.; KLINE, R.G.; MOORE, J.S. Forage animal manegement systems. Virginia Agricultural Experiment Station Bulletin, Virginia, 1986.90p. Virginia Agricultural Experimentation Station, 1986

BOLTON, J.K.; BROWN, R. H. Photosynthesis of grass species differing in carbon dioxide fixation pathway. Plant Physiology, v. 66, p. 97-100,1980.

BOTREL, M. A., GOMIDE, J. A. Importância do teor de carboidratos de reserva e da sobrevivência dos meristemas apicais para a rebrota do capim Jaraguá (Hyparrhenia rufa Stapf). Revista da Sociedade Brasileira de Zootecnia. v.10,n.3, p.411-426, 1981.

BROUGHAM, R. W. Pasture growth rate studies in relation to grazing management. Proceedings of the New Zeland Society of Animal Production, v. 17 ,p. $46-55,1957$.

CALVIERE, I., DURU, M. Leaf appearance and senescence patterns of some pasture species. Grass and Forage Science, v. 50, n.4, p.447-451,1995.

CAIRD, L.; HOMES, W. The prediction of voluntary intake of grazing dairy cows. Journal of Agricultural Science, v. 107, p. 43-54, 1985.

CAMARGO, A.C.de. Produção de leite a pasto. In: CONGRESSO BRASILEIRO DE PLANTAS FORRAGEIRAS, Campinas: C.B.N.A., 1994.

CARVALHO, D. D., DAMASCENO, J. C. Aspectos fisiológicos do capim-elefante cv. Roxo de Botucatu.l. Taxa de Aparecimento, expansão e senescência de folhas. 
In: REUNIÃO ANUAL DA SOCIEDADE BRASILEIRA DE ZOOTECNIA, 33, Fortaleza, 1996. Anais. Fortaleza: SBZ, 1996, p. 4-6.

CHAPMAN, D. F.; CLARK, D.A.; LAND, C. A.; DYMOCK, N. Leaf and tiller growth of Lolium perenne and Agrotis spp. and leaf appearance rates of Trifolium repens in set-stocked and rotationally grazed hill pastures. New Zeland Journal of Agricultural Research. v. 26, p. 159-168,1983.

COLLINS, R. P. ; JONES, M.B. The effects of temperature on leaf growth in Cyperus longus, a temperate c C4 species. Annals of Botany, v. 61,n.3, p. 355-362, 1988.

COMBELAS, J.; HODGSON, J. Herbage intake and milk production by grazing dairy cows. Grass and Forage Science, v. 34, p. 303-310, 1979.

CORSI, M. Pastagens de alta produtividade. In: CONGRESSO BRASILEIRO DE PASTAGENS, Piracicaba, 1986. Anais. Piracicaba: FEALQ,1986. p. 499-512.

CORSI, M. Manejo de plantas forrageiras do gênero Panicum. In: SIMPÓSIO SOBRE O MANEJO DA PASTAGEM, 9., Piracicaba, 1988. Anais. Piracicaba: FEALQ, 1988. p. 57-77.

CORSI, M.; NASCIMENTO, JUNIOR,D. do. Princípios de Fisiologia e morfologia de plantas forrageiras aplicados no manejo das pastagens. In: PEIXOTO, A. M.; MOURA, J. C.; FARIA, V. P. de. Pastagens: fundamentos da exploração racional. 2. ed. Piracicaba: FEALQ, 1994. P. 15-47.

CORSI, M.; BALSALOBRE, M.A.; SANTOS, P.M.; SILVA, S.C. Bases para o estabelecimento do manejo de pastagens de braquiária. In: SIMPÓSIO SOBRE O 
MANEJO DA PASTAGEM, 11., Piracicaba, 1994. Anais. Piracicaba: FEALQ, 1994. p. 249-266.

CORSI, M. ; SANTOS, P. M. Potencial de produção de Panicum maximum. In: SIMPÓSIO SOBRE O MANEJO DA PASTAGEM, 12., Piracicaba, 1995. Anais. Piracicaba: FEALQ, 1995. p. 275-304.

COSTA, N. L., OLIVEIRA,J. R. C. Produção de forragem e composição química de Panicum maximum cv. Tobiatã em diferentes idades de corte. In: REUNIÃO ANUAL DA SOCIEDADE BRASILEIRA DE ZOOTECNIA, 34, Juiz de Fora, 1997. Anais. Juiz de Fora: SBZ, 1997, p. 222-224.

COSTA, C. Estudo da variação na estrutura da vegetação de dois cultivares de Panicum maximum Jacq. (Colonião e Tobiatã) submetidos a diferentes tipos de manejo. Jaboticabal, 1990. 96p. Tese (Doutorado) - Faculdade de Ciência Agrárias e Veterinária de Jaboticabal, Universidade Estadual Paulista "Júlio de Mesquita Filho".

DAVIES, A. The regrowth of grass swards. In: JONES M.B.; LAZEMBY,A. (Ed.) The physiological basis of production. London: Chapman and Hall, 1988, p.85127.

DAVIES, L. Leaf tissue remaining after cutting and regrowth in perenial ryegrass. Journal of Agricultural Science, v. 82, p. 165-172, 1974. 
EUCLIDES, V. P. B. Valor alimentício de espécies forrageiras do gênero Panicum. In: SIMPÓSIO SOBRE O MANEJO DA PASTAGEM, 12., Piracicaba, 1995. Anais. Piracicaba: FEALQ, 1995. p. 97-122.

FALES, S.L. Effects of temperature on fiber concentration, composition, and in vitro digestion kinetics of tall fescue. Agronomy Journal, v. 78, p.963-966, 1986.

FARIA, V. P. de. Produção de bovinos nos trópicos. In: BOVINOCULTURA DE CORTE: Fundamentos da exploração racional. Piracicaba. FEALQ: 1993. p. 2342.

FORD, C. W.; MORRISON, I. M., WILSON, J. R. Temperature effects on lignin, hemicellulose and cellulose in tropical and temperate grasses. Australian Journal of Agricultural Research, v.30,p.621-633, 1979.

FRAME, J. Herbage mass. In: HODGSON, J.; BAKER, R. D.; DAVIES, A.; LAIDLAW, A. S.; LEAVER, J. D. (Ed.) Sward measurement handbook. Berkshrire: The British Grassland Society, 1981, cap. 3, p. 39-71.

FULKERSON, W.J.; SLACK, K. Leaf number as a criterion for determining defoliation time for Lolium perenne: 1. Effect of water soluble carbohydrates and senescence. Grass and Forage Science. v. 49,n.4, p.373-377,1994.

GASTAL, F.; BELANGER,G.; LEMAIRE, G. A model of the leaf extension rate of Tall Fescue in response to nitrogen and temperature. Annais of Botany . v.70,p. $437-442,1992$. 
GASTAL, F.; NELSON, C. J. Nitrogen use within the growing leaf blade of tall fescue. Plant Physiology, v.105, p.191-197,1994.

GOERING, H. K.; VAN SOEST, P.J. Forage fiber analyses (Apparatus, Reagents, Procedures, and Some Applications). Agricultural Handbook $n^{\circ}$ 379. ARSUSDA, Washington, DC, 1970.

GOMIDE, J. A. Princípios de Fisiologia e morfologia de plantas forrageiras aplicados no manejo das pastagens. In: PEIXOTO, A. M.; MOURA, J. C.; FARIA, V. P. de. Pastagens: fundamentos da exploração racional. 2. ed. Piracicaba: FEALQ, 1994. P. 1-14.

GOMIDE, J. A.; OBEID, J. A.; RODRIGUES, L. R. A. Fatores morfofisiológicos de rebrota do capim-colonião. Revista da Sociedade Brasileira de Zootecnia, v. 8, n. 4, p. $532-562,1979$.

GOMIDE, C. A. M.; GOMIDE, J. A. Morfogênese e Análise de Crescimento de cultivares de Panicum maximum. In: REUNIÃO ANUAL DA SOCIEDADE BRASILEIRA DE ZOOTECNIA, 33, Fortaleza, 1996. Anais. Fortaleza: SBZ, 1996, p. 403-405

GOMIDE, J.A.; ZAGO C. P. Valor nutritivo e produtividade do capim colonião, submetido a diferentes intervalos de corte, com e sem adubação de reposição. Revista da Sociedade Brasileira de Zootecnia, v.11,n.3, p. 512-528, 1982 
GOMIDE, J.A. Sistemas de manejo de plantas do gênero Mellinis. In: SIMPÓSIO SOBRE O MANEJO DA PASTAGEM, 9., Piracicaba, 1988. Anais. Piracicaba: FEALQ, 1988. p. 41-57.

GOMIDE, C. A. M. Morfogênese e análise de crescimento de quatro cultivares de Panicum maximum cultivadas em vaso. Viçosa, 1997. Disseração (Mestrado) Universidade Federal de Viçosa. 53 p.

GOMIDE, C.A. M.; GOMIDE, J. A.; QUEIROZ, D. S.; PACIULLO, D. S. C. Fluxo de tecidos em Brachiaria decumbens. In: REUNIÃO ANUAL DA SOCIEDADE BRASILEIRA DE ZOOTECNIA, 34, Juiz de Fora, 1997. Anais. Juiz de Fora: SBZ, 1997, p. 117-119.

GRANT, S. A.; BARTHRAM, G. T.; TORVELL, L. Components of regrowth in grazed and cut Lolium perenne swards. Grass and Forage Science, v.36, n.3, p.155-168.,1981.

HALL, J.D.; BARR, R.; AL-ABBAS, A.H.; L-CRANE, F.L. The ultraesctructure of chloroplasts in mineral-deficient maize leaves. Plant Physiology, v.50, p.404-409, 1972.

HAUN, J. R. Visual quantification of wheat development. Agronomy Journal,v.65, p. $116-119,1973$.

HAY, R. K. M.; WALKER, A. J. Introduction to the physiology of crop yield. 1.ed. Longman Scientific \& Technical, 1989, 292 p. 
HERLING, V. D.; WILMAN, D.; MARES MARTINS, V. M. Senescence and death of herbage during periods of regrowth in ryegrass and red and white clover, and the effect of applied nitrogen. Journal of Applied Ecology, v. 14, p 615-620, 1977

HERNANDEZ, D.; CARBALLO, M.; GARCIA-TRUJlLLO, R; FUNG, C.; MENDOZA, C.; ROBLES, F. Estudio del manejo de Panicum maximum cv. Likoni para la production de leche, III. Variaciones en la disponibilidad de MS por area y su disposicion vertical. Pastos y Forrajes, v. 13, p. 171-177, 1990.

HILLESHEIM, A. Fatores que afetam o consumo e perdas de capim-elefante (Pennicetum purpureum, SHUM.) sob pastejo, Piracicaba, 1987. 94 p. Dissertação (Mestrado) - Escola Superior de Agricultura "Luiz de Queiroz", Universidade de São Paulo, 1987.

HODGSON, J. Grazing management: science into practice. New York: Longman Scientific and Technical, 1990, 203p.

HODGSON, J. ; CLARK, D. A.; MITCHELL, R.J. Foraging behaviour in grazing animais and its impact on plant communities. In: Forage Quality Evaluation, and Utilisation. Palmerston North, 1994. p. 796-827.

HOLMES, C. W.; WILSON, G. F. Milk production from pasture. Butterworths, New Zeland, 1984 p.319

HORST, G. L.; NELSON, C. J.; ASAY, K.H. Relationship of leaf elongation to forage yield of tall fescue genotypes. Crop Science, v. 18, n.5, p. 715-719,1978. 
HSIAO, T. C. Plant responses to waterstress. Annual Review of Plant Physiology, v. 24, p. $59-70,1973$.

HUMPHREYS, L.R. Effects of defoliation on the growth of tropical pastures. In: Humphreys, L.R. (Ed.) Tropical pasture utilization. Cambridge: Cambridge University Press, 1991. cap 4., p. 46 - 65.

JANK, L. Potencial do gênero Panicum. In: Simpósio Brasileiro de Forrageiras e pastagens, 1994. Campinas. Anais S. 1: CBNA, 1994. p.25-31.

JUNG, H. G. Forage lignins and their effects on fibre digestibility. Agronomy Journal, v.81, p. 34-45, 1989.

JUNG, H. G.; VOGEL, K. P. Influence of lignin on digestibility of forage cell wall material. Journal Animal Science v. 62, p. 1703-1712, 1986.

KEMP, D.R.; BLACKLOW, W.M. The responsiveness to temperature of the extension rates of leaves of wheat growing in the field under different levels of nitrogen fertilizer. Journal of Experimental Botany. v. 33, no. 132, p. 29-36, 1982.

KNIRY, J. R.; ROSENTHAL, W. D; JACKSON, B. S.; HOOGENBOON, G. Predicting leaf development of crop plants. In: HODGES, T. (Ed.) Predicting crop phenology. Boca Raton: CRC Press, 1991, p. 29-42.

LAREDO, M. A.; MINSON, D. J. The voluntary intake, digestibility, and retention time by sheep of leaf and stem fractions of five grasses. Australian Jopurnal of Agriculture Research, v. 24, p. 875-888,1973. 
LE DU, Y.L.P. e PENNING, P.D., Animal based techinics for estimating herbage intake. In: Herbage intake handbook. The British Grassland Society, 1982. cap. 3, p. 37-77.

LEMAIRE,G. The phisiology of grass growth under grazing: tissue turn-over. In: Gomide, J. A. SIMPÓSIO INTERNACIONAL SOBRE PRODUÇÃO ANIMAL EM PASTEJO. Viçosa, 1997. Anais. 1997. p.117-144.

MACHADO, A. O.; CECATO, U.; MIRA, R.T.; PEREIRA, L.A.F.; MARTINS, E.N.; DAMASCENO, J. C.; SANTOS, G. T. Avaliação de genótipos de Pamicum maximum (Jacq) em duas alturas de corte. In: REUNIÃO ANUAL DA SOCIEDADE BRASILEIRA DE ZOOTECNIA, 34, Juiz de Fora, 1997. Anais. Juiz de Fora: SBZ, 1997, p. 219-221.

MCMASTER, G. S.; WILHELM, W. W. Accuracy of equations predicting the phyllochron of wheat. Crop Science,v. 35,n.1, p. 30-36, 1995.

MAGALHÃES, A.C.N. Análise quantitativa do crescimento. In: FERRI, M. G. Fisiologia vegetal. São Paulo: EDUSP, 1979. p. 117-163.

MIGLIETTA, F. Simulation of wheat ontogenesis. 1. Appearance of main stem leaves in the field. Climate Research . v.1, p.145-150. 1991.

MICHELL, P.; FULKERSON, W. J. Effect of duration of regrowth intensity in spring on pasture growth, composition and digestibility and on milk production by dairy cows. Australian Journal of Experimental Agriculture,v. 27, n.1, p. 35-40. 1987. 
MINSON, D.J. Nutritional differences between tropical and temperate pastures. In: Grazing Animals. Ed: MORLLEY, F.H.W. Amsterdam: Elsevier, p.143-157. 1980.

MONTEIRO, F.A.; CORRÊA B.D.; MARTIM, R.A.; SANTOS, P.M. Trabalho apresentado à disciplina de Nutrição e Adubação de plantas. Escola Superior de Agricultura "Luíz de Queiroz" - USP. Piracicaba, 1994.

MOORE, K. J.; MOSER, L. E. Quantifying developmental morphology os perennial grasses. Crop Science, v. 35, n.1, p.37-43, 1995.

NABINGER, C. Princípios da Exploração Intensiva de Pastagens. In: SIMPÓSIO SOBRE O MANEJO DA PASTAGEM, 13., Piracicaba, 1997. Anais. Piracicaba: FEALQ, 1997. p. 15-96.

NABINGER C., MEDEIROS R. B. Produção de sementes de Panicum maximum Jacq. In: SIMPÓSIO SOBRE O MANEJO DA PASTAGEM, 12., Piracicaba, 1995. Anais. Piracicaba: FEALQ, 1995. p. 59-128.

NASCIMENTO, M. P. S. C.; NASCIMENTO, H.T.S.; GOMIDE, J. A. Alguns aspectos morfofisiológicos de três gramíneas de clima tropical. Revista da Sociedade Brasileira de Zootecnia. v.9,n.1, p.142-158, 1980.

NELSON, C.J.; ZARROUGH, K. M. Tiller density and tiller weight as yield determinants of vegetative swards. In: WRIGHT, C. E. (Ed.). Plant Physiology and Herbage Production. 1981. p.25-29.

OMETTO, J. C. Bioclimatologia Vegetal. São Paulo: Ed. Ceres. 440p. 1981. 
PARSONS, A. J.; JONHSON, I.R.; WILLIANS, J.H.H. Leaf age structure and canopy photossynthesis in rotationaly and continuously grazed swards. Grass and Forage Science, v. 43, p. 1-14, 1988.

PARSONS, A. J.; PENNING, P. D. The effect of the duration of regrowth on photosynthesis, leaf death and the average rate of growth in a rotationally grazed sward. Grass and Forage Science, v. 43, p. 15-27, 1988.

PARSONS, A .J.; HARVEY A ; WOLEDGE, J. Plant - animal interactions in a continuously grazed mixture. I. Differences in the physiology of leafexpansion and the fate of leaves of grass and clover. Journal of Applied Ecology. v.28 p.619$634,1991$.

PEACOCK, J. M. Temperature and leaf growth in Lolium perenne. .lll. Factors affecting seasonal differences. Journal of Applied Ecology, v.12, n.2, p. 685-97, 1975.

PEARSE, P.J.; WILMAN, D. Effects of applied nitrogen on grass leaf initiation development and death in field swards. The Journal of Agricultural Science, v. 103, n. 2, p. $405-413,1984$

PEDREIRA, J. V. S.; MATTOS, H. B. Crescimento estacional de vinte e cinco espécies ou variedades de capins. Boletim da Indústria animal, v.38, n.2, p. $117-143,1981$.

PINTO, J. C. Crescimento e Desenvolvimento de Andropogon gayanus, Panicum maximum e Setaira anceps cultivadas em vasos, sob diferentes doses de 
nitrogênio. Viçosa, 1993. 149p. Tese (Doutorado) - Universidade Federal de Viçosa.

PINTO, J.C.; GOMIDE, J. A.; MAESTRI, M. Produção de matéria seca e relação folha/caule de gramíneas forrageiras tropicais, cultivadas em vasos, com duas doses de nitrogênio. Revista da Sociedade Brasileira de Zootecnia, v.23, n.3, p. $313-326,1994$ a.

PINTO, J.C.; GOMIDE, J. A.; MAESTRI, M.; LOPES, N. F. Crescimento de folhas de gramíneas forrageiras tropicais, cultivadas em vasos, com duas doses de nitrogênio. Revista da Sociedade Brasileira de Zootecnia, v.23, n.3, p. 327 333,1994 b.

RADIN, J.W.; BOYER, J. S. Control of leaf expansion by nitrogen nutrition in sunflower plants. Plant Physiology, v.69, n.4, p. 771-775, 1982.

ROBSON, M. J. The growth and development of simulated swards of perennial ryegrass. 1: Leaf growth and dry weigth change as related to the ceiling yield of a seedling sward. Annals Botany. v. 37, n. 151, p. 487-500. 1973.

ROBSON, M. J. Potencial production - What it is and can we increase it ? In: WRIGHT C. E. (Ed.). Plant physiology and herbage production. Proceedings of the British Grassland Society, p. 5-17. 1981.

RODRIGUES, L. R. A.; RODRIGUES, T. J. D. Ecofisiologia de plantas forrageiras. In: Ecofisiologia da Produção Agrícola, Piracicaba, Associação Brasileira para Pesquisa da Potassa e do Fosfato, 230 p., 1987. 
SALISBURY, F. B.; ROSS, C. W. Plant physiology. 2.ed. Belmont: Wadsworth, 1978. 422p.

SANTOS, F.A.P. Manejo de pastagens de capim colonião. In: PEIXOTO, A.M.; MOURA, J.C.; FARIA, V. P. de. Volumosos para bovinos. Piracicaba: FEALQ, 1993. p. 21-28.

SARMENTO, C. M. B.; VEIGA, J. B.; COSTA, N. A.; NETO, M.S.; ALVES, L. N. Avaliação de um sistema de pastejo intensivo em pastagem de Tobiatã (Panicum maximum, BRA 001503). In: REUNIÃO ANUAL DA SOCIEDADE BRASILEIRA DE ZOOTECNIA, 34, Juiz de Fora, 1997. Anais. Juiz de Fora: SBZ, 1997, p. 267-270.

SAS User's Guide: Statistics, Version 5 Edition. 1985. SAS Inst., Inc., Cary, NC.

SILVA, S.C da; FARIA, V. P. de; CORSI, M. Sistema intensivo de produção de leite em pastagens de capim-elefante do Departamento de Zootecnia da ESALQ. In: CONGRESSO BRASILEIRO DE GADO LEITEIRO, 2., Piracicaba, 1995. Anais. Piracicaba, 1995, p.97-122.

SILVA, S.C.; PEDREIRA,C.G.S. Fatores condicionantes e predisponentes da produção animal a pasto. In: SIMPÓSIO SOBRE O MANEJO DA PASTAGEM, 13., Piracicaba, 1997. Anais. Piracicaba: FEALQ, 1997, p. 97-122.

SKINNER, R. H.; NELSON, C. J. Effect of tiller trimming on filocrono and tillering regulation during tall Fescue development. Crop Science, v. 34, n.1, p. $1267-$ $1273,1994$. 
SKINNER, R. H.; NELSON, C. J. Elongation of the grass leaf and its relationship to the filocrono. Crop Science, v.35, n.1, p.4-10, 1995.

STOBBS, T. H. The effect of plant structure on the intake of tropical pastures.l. Variation in the bite size of grazing cattle. Australian Journal of Agricultural Research, v. 24, p.809-819, 1973 a.

STOBBS, T. H. The effect of plant structure on the intake of tropical pastures.ll. Differences in sward structure, nutritive value, and bite size of animals grazing Setaria anceps and Choris gayana at various stages of growth. Australian Journal of Agricultural Research, v. 24, p.821-829, $1973 \mathrm{~b}$.

STOCKDALE, C.R.; KING, K. A note on some of the factors that affect the water consumpition of lactating dairy cows at pasture. Animal Production, Edinbugh, v. $36: 303-306,1983$.

TILLEY, J.M.A .; TERREY, R.A . A two stage techinique for the in vitro digestion of forage crops. Journal of the British Grassland Society, v.18, p 104-112, 1963.

THOMAS H.; STODDART, J.L. Leaf senescence. Annual Reviews of Plant Physiology, v.31, p. 83-111, 1980

USBERTI FILHO, J.A. O Agronômico, Edição especial, v.34 (único), 7 p., 1982.

VALLE, L. C. S.; MOZZER, O.L.; VILLAÇA, H. A. et al. Niveis de concentrado para vacas em lactação em pastagens de capim-elefante (Pennisetum purpureum, Schum) no período das águas. In: REUNIÃO ANUAL DA SOCIEDADE BRASILEIRA DE ZOOTECNIA, 24, Brasília. Anais. Brasília, 1987, 56p. 
VAN LOO, E. N. Tillering, leaf expansion and growth of plants of two cultivars of perennial ryegrass grown using hydroponics at two water potencials. Annals of Botany, v. 70, p. 511-518,1992.

VAN SOEST, P. J. Nutricional ecology of the ruminants. 2.ed. Cornell: Cornell University Press, 1994. 476p.

WIHELM, W. W.; McMASTER, G. S. Importance of the filocrono in studing development and growth in grasses. Crop Science. v. 35, n. 1, p.1-3, 1995.

WILSON, J. R. Organization of plant tissues. In: JUNG, H. G.; BUXTON, D. R.; HATFIELD, R. D.; RALPH, J. (Eds.) Forage Cell Wall Structure and Digestibility. Wisconsin, p. 1-27, 1993.

WILSON, J. R.; MINSON, D. J. Prospects for improving the digestibility and intake of tropical grasses. Tropical Grassland. v. 14, p. 253-259, 1980.

WILSON, J. R. Cell wall characteristics in relation to forage digestion by ruminants. Journal of Agricultural Science, v. 122, p. 173-182, 1994. 